\title{
British Bryological Society Expedition to Mulanje Mountain, Malawi. 13. New and other unpublished records
}

\author{
B J. O'Shea', M.J. Wigginton², M.A. Bruggeman-Nannenga ${ }^{3}$, N.G. \\ Hodgetts $^{4}$ \& R.D. Porley ${ }^{5}$ \\ 1 141, Fawnbrake Avenue, London, SE24 OBG, UK \\ ${ }^{2} 36$ Big Green, Warmington, Peterborough, PE8 6TU, UK \\ ${ }^{3}$ Department of Plant Ecology, Herbarium Division, Heidelberglaan 2, NL 3584 CS \\ Utrecht, The Netherlands \\ ${ }^{4}$ Joint Nature Conservation Committee, Monkstone House, City Road, Peterborough, PE1 \\ 1JY, UK \\ ${ }^{5}$ English Nature, Foxhold House, Crookham Common, Thatcham, Berks., RG19 8EL, UK
}

\begin{abstract}
Further results are provided of the 1991 British Bryological Society Expedition to Mulanje Mt., Malawi including 168 taxa of bryophyte, comprising 72 taxa of liverwort (38 new to Malawi) and 96 taxa of mosses (45 new to Malawi).
\end{abstract}

\section{INTRODUCTION}

This paper provides further results of the British Bryological Society (BBS) Expedition to Mulanje Mountain, 16 June-1 July 1991, the background and site details of which are described in Longton (1993). We also publish here records of some Fissidens spp. collected by T. Pócs, Z. Magombo and C.C. Townsend (among others), and details of other collections made by D.G. Long and J. Rammeloo. A number of identifications have been made in genera yet to be revised, and it has not been possible to check all of these against types. Where comment is made about any taxon, the author's initials are added in square brackets.

Nomenclature follows O'Shea (1999) for mosses, and Wigginton \& Grolle (1996) for liverworts, except where otherwise stated. All localities are from Mulanje Mt. unless stated otherwise, and the known African distribution of the taxon is given. Many of the BBS expedition collections await examination, and additional collections of taxa listed in this paper are to be expected. The collection numbers are prefixed by ' $M$ ' on the packets, but the letter has been omitted from numbers cited in this paper. The collections are held at the Royal Botanic Garden, Edinburgh (E), except those of C.R. Stevenson which are in Hb. Stevenson. Selected duplicate 
material is held at the National Herbarium of Malawi, Zomba (MAL), the Missouri Botanical Garden, St. Louis (MO), and the University of Reading, England (RDG).

Alan Crundwell has been of great support to the BBS Tropical Bryology Group since its inception, and collected many of the Malawi records. Despite his illness he undertook to look at both Bryaceae and some Dicranaceae from our collections, but had only partly completed this at the time of his death. All the collections he identified are included in this paper.

Abbreviations:

$$
\begin{aligned}
& \mathrm{NP}=\text { National Park } \\
& *=\text { new to Malawi }
\end{aligned}
$$

\section{LIVERWORTS}

\section{ACROBOLBACEAE}

*Marsupidium limbatum (Steph.) Grolle Ruo Gorge, $15^{\circ} 55^{\prime} \mathrm{S} 35^{\circ} 38^{\prime} \mathrm{E}$, on branches of small tree, 1830 m, 20 June 1991, Porley 136a, det. R. Grolle, conf. T. Pócs. An apparently very local species, recorded elsewhere in Africa only from Tanzania, South Africa, Mauritius and Réunion.

*Tylimanthus ruwenzorensis S.W.Arnell Fairly widespread on Mulanje Mt., with collections from the Ruo Gorge, Minunu, Nessa path, Lichenya plateau and valleys, Chinzama, Thuchila plateau and the path to Chambe, 1690$2220 \mathrm{~m}$, with one record from $1260 \mathrm{~m}, 16-28$ June 1991. It occurred in small pure patches or as scattered stems intermixed with other bryophytes: on sandy or peaty soil on open banks and between tussocks on grassland, on river alluvium, on dry or damp, shaded rocks (sometimes in the spray zone of waterfalls or on rocks subject to periodic inundation), also found on the rotting bark of a forest tree and on a treefern stem. Wigginton 1364b, 1462a, 1643b; Hodgetts 2024i, 2068d, 2150b, 2187b, 2428b, 2597c; Kungu 3142a, 3193a; Magombo 4170c, 4178a; Kathumba 5960a; Longton 8159a; all det. N.G. Hodgetts or M.J. Wigginton. The other African records are from Ghana, Ethiopia, Rwanda, Kenya, Tanzania, Uganda and Réunion.

\section{ANEURACEAE}

*Aneura pseudopinguis (Herzog) Pócs Minunu path, Ruo valley, $15^{\circ} 58^{\prime} \mathrm{S} 35^{\circ} 32^{\prime} \mathrm{E}$, on dead wood under forest cover, $1850 \mathrm{~m}, 20$ June 1991, Magombo 4126a, det. M.J. Wigginton. Tropical and southern Africa. There only a few confirmed records, but its distribution is obscured by past confusion with A. pinguis; Meenks \& Pócs (1985) describe the differentiating characters. [MJW]

\section{ANTHOCEROTACEAE}

Phaeoceros carolinianus (Michaux.) Prosk. Muluzi River, E. of Songwe, $16^{\circ} 0^{\prime} \mathrm{S} 35^{\circ} 43^{\prime} \mathrm{E}$, shaded damp soil by river, $740 \mathrm{~m}, 18$ June 1991 , Porley 7la. Chisongoli, $16^{\circ} 0^{\prime} \mathrm{S} 35^{\circ} 43^{\prime} \mathrm{E}$, damp vertical rock on path, $1530 \mathrm{~m}, 17$ June 1991, Hodgetts 2201a. Nessa path, Lichenya plateau, $15^{\circ} 58^{\prime} \mathrm{S} 35^{\circ} 33^{\prime} \mathrm{E}$, pathside at forest edge, 1830 m, 27 June 1991, Hodgetts 2578a. Minunu path, Ruo Gorge, $15^{\circ} 55^{\prime} \mathrm{S} 35^{\circ} 38^{\prime} \mathrm{E}$, on soil bank by path, 1900 m, 19 June 1991, Kungu 3065a. Lichenya plateau, near CCAP Hut, $15^{\circ} 57^{\prime} \mathrm{S}$ $35^{\circ} 32^{\prime} \mathrm{E}$, damp soil by path, $1980 \mathrm{~m}, 26$ June 1991, Magombo 4314a. Likhubula River, 15'56'S 35³0'E, soil on river bank, 850 m, 30 June 1991, Magombo 4402a. Little Lujeri River, $15^{\circ} 58^{\prime} \mathrm{S} 35^{\circ} 37^{\prime} \mathrm{E}$, on granitic boulder in open woodland, $980 \mathrm{~m}, 17$ June 1991, O'Shea $7037 a$. Thuchila to Lukhulezi path, $15^{\circ} 52^{\prime} \mathrm{E} 35^{\circ} 36^{\prime} \mathrm{E}$, on sandy soil in gully in Brachystegia woodland, and on dry sandstone rocks, $1800 \mathrm{~m}, 23$ June 1991, Longton 8347a, 8356a. Chambe Basin, $15^{\circ} 55^{\prime} \mathrm{S} 35^{\circ} 33^{\prime} \mathrm{E}$, soil bank by path, $2000 \mathrm{~m}, 24$ June 1991, Longton 8388a. All collections det. J. Hasegawa. Collections Magombo 4098a, and Longton $8637 a$ have been determined by $\mathrm{J}$. Hasegawa as Phaeoceros aff. carolinianus. Other Malawi records are from Blantyre, Dedza and Mulanje Districts. Widespread in tropical and southern Africa.

\section{BALANTIOPSACEAE}

*Isotachis aubertii (Schwaegr.) Mitt. Fairly widespread on Mulanje Mt., with most collections from the Lichenya area, and also from Sombani, Malosa pools, the slopes of Chagaru, 
Thuchila and by the path from Lichenya to Chambe. Collections were from 1700-2550 m, except for one from Little Lujeri at $1200 \mathrm{~m}$. Found on moist gravelly, sandy and peaty soils on paths and by streams, and on sandstone and granitic rocks, usually in pure clumps, but sometimes intermixed with other bryophytes including Symphyogyna, Jungermannia, Campylopus and Sphagnum. Porley 131b, 176a, 303a, 306a; Wigginton 1305b, 1309a, 1668a, 1669a, 1675a, 1721a; Hodgetts 2120c, 2168c, 2182b, 2188d, 2335c, 2582a; Kungu 3114a; Russell 6091a, 6106b; O'Shea 7215b, 7216a, 7456a, 7520a; Longton 8028a, 8479a. All collections det. or conf. M.J. Wigginton. A very variable species in its size, habit and colour, widespread in tropical and southern Africa, and the East African islands. [MJW]

\section{CEPHALOZIACEAE}

All collections have been identified or confirmed by M.J. Wigginton, unless otherwise indicated.

*Alobiellopsis heteromorpha (Lehm.) R.M.Schust. Fairly widespread on Mulanje Mt., which is its most northerly known location. Near Minunu Hut, 1555'S 35³8'E, 1860-1900 m, 20 June 1991, soil in deeply-shaded recess under tree overhanging river, with Calypogeia arguta, Pogonatum sp., Porley 141b; moist, open, sandy soil on firebreak, and with Gottschelia schizopleura and Cephaloziella kiaeri in open Helichrysum-grass community, Wigginton $1268 a, 1270 a$, conf. R. Grolle. Slopes of Chagaru, $15^{\circ} 53^{\prime} \mathrm{S} 35^{\circ} 39^{\prime} \mathrm{E}$, peaty humus in shady rock cleft by mountain spring, with Notoscyphus lutescens, Isotachis aubertii, Symphyogyna brasiliensis, Jungermannia borgenii, 2280 m, 21 June 1991, Wigginton 1319a, conf. R. Grolle. Upper Ruo River, 55³1'S 35³8'E, peaty bank by river, 1860 m, 20 June 1991, Hodgetts 2120 e. Lichenya plateau, near CCAP hut, $15^{\circ} 57^{\prime} \mathrm{S}$ 35'32'E, moist soil on riverbank, $1980 \mathrm{~m}, 26$ June 1991, Magombo 4316a, 4317a, 4319a. Chinzama to Sombani path, $15^{\circ} 53^{\prime} \mathrm{S} 35^{\circ} 39^{\prime} \mathrm{E}$, damp hollow by path, $2260 \mathrm{~m}, 20$ June 1991, Longton 8192a. Otherwise recorded only in Lesotho, South Africa and Mauritius.

Cephalozia bicuspidata (L.) Dumort. Slopes of
Chagaru, $15^{\circ} 53^{\prime} \mathrm{S} 35^{\circ} 39^{\prime} \mathrm{E}$, on peat in crevice by mountain stream, $2280 \mathrm{~m}, 21$ June 1991, Wigginton 1309a, det. J. Váňa. Near Chinzama hut, $15^{\circ} 53^{\prime} \mathrm{S} 35^{\circ} 39^{\prime} \mathrm{E}$, moist soil patch in grassland, $2140 \mathrm{~m}, 21$ June 1991, Wigginton 1365b. Stream in Ruo Basin near Chinzama Hut, $15^{\circ} 53^{\prime} \mathrm{S} 35^{\circ} 39^{\prime} \mathrm{E}$, on soil of river bank, moist place, 1200 m, 21 June 1991, Magombo 4212b, det. T. Pócs. Chinzama to Thuchila path, $15^{\circ} 53^{\prime} \mathrm{S}$ $35^{\circ} 37^{\prime} \mathrm{E}$, thin peaty humus overlying granitic rock, 2120 m, 22 June 1991, Kungu 314la. Bank of Lichenya River, $2 \mathrm{~km} \mathrm{SW}$ of Sapitwa, $15^{\circ} 57^{\prime} \mathrm{S}$ $35^{\circ} 34^{\prime} \mathrm{E}$, on soil beneath shaded overhang, intermixed with Isotachis aubertii, $2550 \mathrm{~m}, 28$ June 1991, Russell 6106a. Also recorded from Zomba plateau. East and southern Africa, and Réunion.

*Cephalozia connivens ssp. fissa (Steph.) Váňa (C. fissa Steph.) Upper Ruo Forest, $15^{\circ} 55^{\prime} \mathrm{S}$ $35^{\circ} 38^{\prime} \mathrm{E}$, wet peaty soil on shaded rock, scattered stems in mat of Bazzania nitida, Telaranea nematodes and Lophocolea sp., 1960 m, 20 June 1991, Wigginton 1202a, conf. J. Ván̆a. Near Lichenya River, $15^{\circ} 58^{\prime} \mathrm{S} 35^{\circ} 33^{\prime} \mathrm{E}$, on shaded sandstone rock, 1720 m, 27 June 1991, Wigginton 1633b. Stream in Ruo Basin near Chinzama Hut, 15'53'S 35'39'E, on soil of river bank, moist place, 1200 m, 21 June 1991, Magombo 4212c, det. T. Pócs. Thuchila to Lukhulezi path, $15^{\circ} 52$ 'S $35^{\circ} 36^{\prime} \mathrm{E}$, sheltered bank of stream, $1800 \mathrm{~m}, 23$ June 1991, O'Shea 7384a. Chinzama to Sombani path, $15^{\circ} 53$ 'S $35^{\circ} 40^{\prime} \mathrm{E}$, peaty soil at base of rock, 2215 m, 20 June 1991, Longton 8200a. Tropical and southern Africa, including East African islands.

*Iwatsukia jishibae (Steph.) N.Kitag. Ruo Forest, $15^{\circ} 55^{\prime} \mathrm{S} 35^{\circ} 38^{\prime} \mathrm{E}$, on bark of fallen Widdringtonia cupressoides, 1900-1950 m, 17 June 1991, Porley $117 a$ (det. J. Váňa), Hodgetts 2096a. Thuchila plateau, $15^{\circ} 53^{\prime} \mathrm{S} 35^{\circ} 35^{\prime} \mathrm{E}$, with Bazzania decrescens on trunk of Widdringtonia, at forest edge, $1690 \mathrm{~m}, 23$ June 1991, Wigginton 1456b. Thuchila Plateau, $15^{\circ} 53^{\prime}$ 'S $35^{\circ} 36^{\prime} \mathrm{E}$, tree trunk in forest, $1780 \mathrm{~m}, 23$ June 1991, Hodgetts $2346 a$, det. J. Váňa. Chambe Basin, $15^{\circ} 54^{\prime}$ S $35^{\circ} 32^{\prime} \mathrm{E}$, on dry bark of mature Widdringtonia tree in mixed forest, $1890 \mathrm{~m}, 25$ June 1991, Wigginton 1569a. The first records for mainland 
Africa, and subsequently recorded in Bioko (Müller, 1996). Also known from the Comoro Islands, Madagascar, Mauritius, the Seychelles and Réunion, and disjunct in Costa Rica, the Himalayas, Japan and Papua New Guinea. [MJW]

Odontoschisma africanum (Pearson) Sim Upper Ruo Gorge, $15^{\circ} 55^{\prime} \mathrm{S}$ 35 $38^{\circ}$ 'E, shaded peaty soil bank by path in forest, 1950-1970 m, 20 June 1991, Porley 123a, Wigginton 1255a, det. R. Grolle. Makhutula River, 1556'S $35^{\circ} 33^{\prime} \mathrm{E}$, dry peaty bank by river in wooded ravine, $2080 \mathrm{~m}$, 26 June 1991, Wigginton 1612b. Nessa path, Lichenya plateau, $15^{\circ} 59^{\prime} \mathrm{S} 35^{\circ} 33^{\prime} \mathrm{E}$, on base of grass tussock, 1780 m, 28 June 1991, Magombo 4380a. Minunu path, Ruo Valley, $15^{\circ} 56^{\prime} \mathrm{S} 35^{\circ} 38^{\prime} \mathrm{E}$, humus on base of tree in midaltitude forest, 1720 m, 18 June 1991, Longton 8097a. Noted in Pócs (1990) as occurring in Malawi, but without details. In Africa, otherwise only from South Africa, Tanzania and Mauritius.

\section{CEPHALOZIELLACEAE}

Cephaloziella kiaeri (Austin) Douin Widespread on Mulanje Mt.: collections from Chisongoli, Upper Ruo forest, slopes of Chagaru and Namasile, Chinzama, Thuchila plateau and Red Route shelter. It was found on peaty soil by streams, on rock exposures, in soil patches in montane grassland, usually intermixed with other bryophytes, $1220-2325 \mathrm{~m}$. Selected collections: Wigginton 1016a, 1249a, 1280a, 1332a; Hodgetts 2059c, 2148b, 2195c, 2328b, 2429b; all det. J. Ván̆a. In Malawi, also on the Zomba plateau. Recorded from Cameroon, and from East and southern Africa.

*Cephaloziella transvaalensis S.W.Arnell Below Chinzama Hut, 1553'S 35³9'E, shaded peaty soil by stream, $2260 \mathrm{~m}, 21$ June 1991 , Hodgetts $2168 d$, det. J. Váňa. Otherwise recorded only from South Africa.

*Cephaloziella umtaliensis S.W.Arnell Chisongoli, $16^{\circ} 0$ 'S $35^{\circ} 43^{\prime} \mathrm{E}$, on shaded granitic rock on forest path, 1500-1560 m, 17 June 1991, Porley 56a; Wigginton 1104a; both det. J. Ván̆a. The only other African records are from
Mozambique and Zimbabwe.

*Cephaloziella vaginans Steph. Chinzama, $15^{\circ} 53^{\prime} \mathrm{S} 35^{\circ} 39^{\prime} \mathrm{E}$, on earth bank in tussock grassland community with Gongylanthus ericetorum, and on shaded vertical peaty streambank, 2120-2175 m, 21 June 1991, Porley $158 b$, Hodgetts $2139 b$, both det. J. Váňa. Elsewhere, records from Cameroon, D.R. Congo, Rwanda and Tanzania, and with doubt from Sierra Leone.

\section{FRULLANIACEAE}

Many of the BBS collections of Frullania from Mulanje Mt. have yet to be examined, in particular those of B.J. O'Shea and R.E. Longton. All collections have been determined or confirmed by N.G. Hodgetts unless otherwise indicated.

Frullania angulata var. angulata Mitt. Quite widely collected - Chinzama, Nessa path (Lichenya), Ruo Gorge, Sombani and Thuchila, 1680-2295 m, 17-30 June 1991. Mainly on the trunks, branches and twigs of trees and shrubs, in shade or in the open; sometimes on tree stumps, rotting and dead wood; also growing over filmy ferns on rock ( 1 coll.) and on the base of a fern on a valley slope (1 coll.). Porley (4); Wigginton (5); Hodgetts (16); O'Shea (1); Longton (2). RUMPHI: Nyika plateau, $10^{\circ} \mathrm{S} 33^{\circ} \mathrm{E}$, epiphytic on tree branches, 2295 m, 30 July 1993, Stevenson CRS075. Previous Malawi records from Mulanje and Thyolo Districts. Widespread in tropical Africa.

*Frullania apicalis Mitt. Chisongoli Forest, $16^{\circ} 0^{\prime} \mathrm{S} 35^{\circ} 43^{\prime} \mathrm{E}$, on trunks of Julbernadia and other trees, 1200 m, 17 June 1991, Porley 61b, Wigginton 1122c; trunks and branches of forest trees, 1625-1680 m, 17 June 1991, Wigginton $1040 c, 1087 a, 1099 a$. Upper Ruo Forest, $15^{\circ} 55^{\prime} \mathrm{S}$ $35^{\circ} 38^{\prime} \mathrm{E}$, on trees and shrubs, 1850-1880 m, 20 June 1991, Wigginton 1248a; Hodgetts 2079e, 2081a. Minunu, $15^{\circ} 55^{\prime} \mathrm{S} 35^{\circ} 38^{\prime} \mathrm{E}$, on tree by river, 1870 m, 20 June 1991, Hodgetts 2132b. Thuchila plateau, $15^{\circ} 53$ 'S $35^{\circ} 36^{\prime} \mathrm{E}$, on tree trunk, fallen tree and rock, 1680-1720, Hodgetts 2365 a, 2591a. Slopes of Chagaru, 1552'S 35³9'E, on old Vellozia tree, 2410 m, 21 June 1991, Hodgetts $2175 c$. Widespread in tropical Africa. 
Frullania caffraria Steph. By side of Chapaluka Path to Chambe, 1625 m, 7 August 1993, Stevenson CRS153. RUMPHI: Nyika NP, $10^{\circ} \mathrm{S}$ $33^{\circ} \mathrm{E}$, on rocks, $2165 \mathrm{~m}, 30$ July 1993, Stevenson CRSO54. Both collections det. C.R. Stevenson. The three other records from Malawi are from Dedza and Blantyre districts (O'Shea, 1993). Widespread in tropical Africa.

*Frullania capensis Gottsche Widespread on Mulanje Mt.: Chinzama, Chisongoli, Lichenya plateau, Upper Ruo Gorge, Thuchila and S. of Bandiwo, 1200-2225 m, 17-28 June 1991. Trunks, branches and twigs of forest trees and shrubs, lianes, shrubs in open grassland, occasionally on rocks and the base of fern tussocks. Porley 161a; Wigginton 1122b; Hodgetts 2052a, 2071e, 2096b, 2110a, 2133e, 2185e, 2246a, 2261a, 2271a, 2320c, 2344b, $2378 g, 2575 k, 2592 a, 2592 b$. Local in East Africa (Tanzania, Mozambique, Zimbabwe, South Africa), and East African islands.

*Frullania depressa Mitt. Apparently rare on Mulanje Mt. with only a single record. Ruo Basin opposite Chinzama Hut, $15^{\circ} 53$ 'S 35³9'E, on isolated tree in sunny position above gully in plateau grassland, 2175 m, 21 June 1991, Porley $156 a$, det. N.G. Hodgetts. Quite widespread in tropical and southern Africa; also Madagascar.

*Frullania diptera (Lehm.) Drège NKHATA BAY. Kasito Lodge, Luwawa Forestry Reserve, Chikangawa, 11 ${ }^{\circ} 47^{\prime} \mathrm{S} 33^{\circ} 49^{\prime} \mathrm{E}$, on tree branches, 1700 m, 29 July 1993, Stevenson CRSO33, det. C.R. Stevenson. Local in tropical and southern Africa.

*Frullania eplicata Steph. Apparently rare on Mulanje Mt.: 1.5 km E of Red Route Shelter, by path to Thuchila plateau, $15^{\circ} 55^{\prime} \mathrm{S} 35^{\circ} 35^{\prime} \mathrm{E}$, on twigs on tree in ravine, $2080 \mathrm{~m}$, 24 June 1991, Hodgetts 2410a, det. N.G. Hodgetts. Otherwise recorded only in Ghana, D.R. Congo, Tanzania, Mozambique, Zambia and Zimbabwe.

Frullania ericoides (Nees) Mont. Near Muluzi river, Chisongoli, $16^{\circ} 1^{\prime} \mathrm{S} 35^{\circ} 43^{\prime} \mathrm{E}$, trunk of Macaranga tree, on rocks and on base of
Eucalyptus, 740-760 m, 18 June 1991, Wigginton 1140a; Hodgetts 2035a, 2037a. Chisongoli Forest, $16^{\circ} 1$ 'S $35^{\circ} 43^{\prime} \mathrm{E}$, on Julbernadia and other trees, 1200 m, 17 June 1991, Porley 61a (det. R.D. Porley); Wigginton 1123a; Hodgetts $2270 a$. Near Lichenya River, $15^{\circ} 58^{\prime}$ 'S 35 33'E, on trunk of forest tree, 1740 m, 26 June 1991, Hodgetts 2499c. Nessa path, Lichenya, 1559'S 35³3'E, trunk of tree at forest margin, $1820 \mathrm{~m}, 28$ June 1991, Hodgetts 2580c. The other Malawi records are from Blantyre District. Common and widespread throughout tropical and southern Africa.

*Frullania grossiclava Steph. Gorge of Muluzi River, below Hutson's house, $16^{\circ} 1$ 'S $35^{\circ} 42^{\prime} \mathrm{E}$, trunk of old Macaranga tree in well-illuminated site by river, 760 m, 18 June 1991, Wigginton $1138 a$, det. T. Pócs. Apparently very local in Africa, with records only from D.R. Congo, Mozambique, Tanzania, Zimbabwe and Madagascar.

*Frullania lindenbergii Lehm. By Minunu path, Ruo valley, $15^{\circ} 55^{\prime} \mathrm{S} 35^{\circ} 38^{\prime} \mathrm{E}$, on tree trunk, shrub, fallen twigs and base of fern, 1850-1880 m, 20 June 1991, Wigginton 1248b; Hodgetts 2071f, 2081d, 2086c, 2133f. Chisongoli, 160'S $35^{\circ} 43^{\prime} \mathrm{E}$, on shrub in forest understorey, 1680 m, 17 June 1991, Hodgetts 2239b. Thuchila plateau, $15^{\circ} 53^{\prime} \mathrm{S} 35^{\circ} 36^{\prime} \mathrm{E}$, on bough of Pterocarpus tree, 1980 m, 22 June 1991, Hodgetts 2320d; foliicolous on forest shrub, 1750 m, 23 June 1991, Hodgetts 2378s. East African mainland and islands.

Frullania loricata Pearson Ruo Basin near Chinzama Hut, $15^{\circ} 53$ 'S $35^{\circ} 39^{\prime} \mathrm{E}$, on a tree above a stream gully, $2280 \mathrm{~m}, 21$ June 1991, Hodgetts $2169 b$. Lichenya, forest below Hut, $15^{\circ} 58^{\prime} \mathrm{S}$ $35^{\circ} 33$ 'E, small piece on bank, probably fallen from the tree canopy, $1740 \mathrm{~m}, 26$ June 1991, Hodgetts 2501d. Both det. N.G. Hodgetts. One previous records from Malawi (Mulanje Mt.). Otherwise known only from Tanzania, Uganda and Madagascar.

Frullania obscurifolia Mitt. For such a widespread African species, surprisingly few records were made on Mulanje Mt. By Muluzi 
River, Chisongoli, $16^{\circ} 1^{\prime} \mathrm{S} 35^{\circ} 42^{\prime} \mathrm{E}$, on trunk of Eucalyptus, 740 m, 18 June 1991, Hodgetts 2031b. Chisongoli, $16^{\circ} 1^{\prime}$ 'S $35^{\circ} 43^{\prime} \mathrm{E}$, on dry bark of Julbernadia, 1200 m, 17 June 1991, Wigginton $1122 a$ (det. M.J. Wigginton). Chambe Basin, $15^{\circ} 54^{\prime} \mathrm{S} 35^{\circ} 32^{\prime} \mathrm{E}$, on trunk of Trichlia emetica and Cupressus macrocarpa, 1900 m, 25 June 1991, Wigginton 1546b; Longton 8391a. NKHATA BAY. Side of M5 road, Vizava Rubber Estate, S. of Nkhata Bay, $11^{\circ} 38^{\prime} \mathrm{S}$ $34^{\circ} 14^{\prime} \mathrm{E}$, epiphytic on rubber tree, $580 \mathrm{~m}, 1$ August 1993, Stevenson CRSO82, CRS083, both det. C.R. Stevenson. The other Malawi records are from Limbe and Ndirande, Blantyre District. Widespread and frequent in tropical and southern Africa.

Frullania serrata Gottsche Lichenya, forest below Hut, $15^{\circ} 58^{\prime} \mathrm{S} 35^{\circ} 33^{\prime} \mathrm{E}$, pendent on forest tree, 1740 m, 26 June 1991, Hodgetts 2507d. Nessa Path, Lichenya Plateau near Boma Hut, $15^{\circ} 59^{\prime} \mathrm{S} 35^{\circ} 33^{\prime} \mathrm{E}$, branch of forest tree, $1820 \mathrm{~m}$, 28 June 1991, Hodgetts 2610c. One previous record from Mulanje Mt. An almost exclusively East African species (and islands), but recorded also from Cameroon.

Frullania trinervis (Lehm.) Drège By Muluzi River, Chisongoli, $16^{\circ} 1^{\prime} \mathrm{S} 35^{\circ} 42^{\prime} \mathrm{E}$, on Eucalyptus, 740 m, 18 June 1991, Hodgetts 2032a. Chisongoli, $16^{\circ} 0^{\prime} \mathrm{S} 35^{\circ} 43^{\prime} \mathrm{E}$, on Eucalyptus, 1490 m, 17 June 1991, Hodgetts $2263 b$. Thuchila to Chambe path, on twigs and liane in forest, 2020-2080 m, 24 June 1991, Hodgetts 2401d, 2410h. The Crater, 16 ${ }^{\circ}$ 's $35^{\circ} 32^{\prime} \mathrm{E}$, on rotting trunk lying across stream, 950 m, 30 June 1991, Hodgetts 2683c. Road through Chitakali estate, Mulanje village, $16^{\circ} 1$ 'S $35^{\circ} 31$ 'E, on roadside tree, $620 \mathrm{~m}, 1$ July 1991 , Hodgetts 2699b, 2700d. By side of Chapaluka Path to Chambe, $15^{\circ} 55^{\prime} \mathrm{S} 35^{\circ} 32^{\prime} \mathrm{E}$, on dry rocks, 1420 m, 7 August 1993, Stevenson 136, det. C.R. Stevenson. Widespread in Africa.

*Frullania variegata Steph. MZIMBA. By M1 road, c. $5 \mathrm{~km} \mathrm{~S}$. of M20 turnoff, Viphya Mts., $12^{\circ} 6^{\prime} \mathrm{S} 33^{\circ} 38^{\prime} \mathrm{E}$, on branch of Brachystegia in montane forest, $1500 \mathrm{~m}, 28$ July 1993, Stevenson CRS001, det. C.R. Stevenson. Local in Cameroon, East Africa and the East African islands.

\section{JUNGERMANNIACEAE}

All collections have been determined or confirmed by M.J. Wigginton, unless otherwise indicated.

*Anastrophyllum auritum (Lehm.) Steph. Apparently local on Mulanje Mt. and restricted to the higher altitudes, with collections from Red Route Shelter between Chinzama and Thuchila, the slopes of Nandiwo and Sapitwa, 2120-2990 m, 22-28 June 1991. Mostly found on damp freely drained soil, on rocks and in rock crevices, with one collection epiphytic on Erica arborea. Associates included Kurzia capillaris, Symphyogyna brasiliensis on rock, Gottschelia schizopleura on soil. Porley 245b; Hodgetts 2185c, 2429g, 2456c, 2482a; Magombo 4274a; Russell $6123 \mathrm{c}$. Cameroun, mountains in tropical and southern Africa, including subantarctic islands.

*Anastrophyllum piligerum (Nees) Steph. Lower Ruo Forest, 1557'S 35³9'E, on buttress of tree in sheltered forest glade, with other robust species including Chandonanthus hirtellus, Plagiochila sp., Mastigophora diclados, 10201050 m, 19 June 1991, Porley 96b; Wigginton $1184 b$ (det. E.W. Jones), 1186b; Hodgetts 2043a; on tree branch, in mixed mat with Sphagnum, Radula, etc., 990 m, 18 June 1991, O'Shea 7068b. Upper Ruo Gorge, $15^{\circ} 55^{\prime} \mathrm{S} 35^{\circ} 38^{\prime} \mathrm{E}$, on very rotten tree stump by path in forest $1800 \mathrm{~m}$, 19 June 1991, Hodgetts 2054a; vertical peaty bank by river, $1860 \mathrm{~m}$, Hodgetts $2127 a$, det. J. Váňa. South of Nandiwo, $15^{\circ} 53^{\prime}$ S $35^{\circ} 38^{\prime}$ E, damp rock crevices where path crosses stream, 2150 m, 22 June 1991, Hodgetts 2185b, conf. J. Ván̆a. Between Chinzama and Thuchila, $15^{\circ} 53$ 'S $35^{\circ} 38^{\prime} \mathrm{E}$, on damp face of granitic boulder by stream, 2150 m, 22 June 1991, Porley 175a. Little Lujeri, $15^{\circ} 58^{\prime} \mathrm{S} 35^{\circ} 37^{\prime} \mathrm{E}$, on granitic rocks by river, 1200 m, 17 June 1991, Longton 8022a. Local in Africa, and otherwise known only from Rwanda, Tanzania, Zimbabwe, the East African islands and Ascension.

*Chandonanthus birmensis Steph. Minunu path, Ruo valley, $15^{\circ} 56^{\prime} \mathrm{S} 35^{\circ} 38^{\prime} \mathrm{E}$, on tree trunk in dappled shade by forest path, $1850 \mathrm{~m}, 20$ June 
1991, Hodgetts 2081b. Ruo River, $15^{\circ} 55^{\prime} \mathrm{S}$ $35^{\circ} 38^{\prime} \mathrm{E}$, on dry surface of exposed rock, with Syrrhopodon prolifer, $1830 \mathrm{~m}$, Wigginton 1279a, det. R. Grolle. Just below summit of Sapitwa, $15^{\circ} 56^{\prime} \mathrm{S} 35^{\circ} 35^{\prime} \mathrm{E}$, by pool under rock, $2990 \mathrm{~m}$, Hodgetts 2456a, det. R. Grolle. Nessa path, Lichenya plateau, $15^{\circ} 59^{\prime} \mathrm{S} 35^{\circ} 33^{\prime} \mathrm{E}$, on bark of forest tree, 1780 m, 28 June 1991, Magombo 4273a. The only other African records are from Madagascar; it is recorded also in India, Nepal, and East and South-East Asia. C. birmensis is described and illustrated in Kitagawa (1965) and Tewari \& Airi (1988).

Chandonanthus hirtellus ssp. hirtellus (F.Weber) Mitt. Collections from across the Mulanje Mt. plateau, including from Lichenya, Minunu, Ruo Gorge, Sombani, and by the Chinzama to Thuchila, and Thuchila to Lukhulezi paths, 980-2120 m, 18-27 June 1991.

On tree trunks and branches; on shaded and exposed rocks; earth banks; sometimes on rotting logs. Wigginton 1245b, 1253a; Hodgetts 2053c, 2157c, 2436b; Kungu 3147a, 3339a; Magombo 4160a; Kathumba 5072a, 5075a, 5141a, 5143a; O'Shea 7067a, 7094a, 7401a; Longton 8177a, $8234 a, 8269 a, 8315 a$.

Recorded also from the Zomba plateau. Mountains in West Africa (Sierra Leone, Cameroun), and in the east from Ethiopia to South Africa, and widespread in the East African islands.

Plants of $C$. hirtellus from the BBS collections vary considerably in size, the leaf-length ranging, without appreciable discontinuity, between 0.8 $\mathrm{mm}$ and $2.2 \mathrm{~mm}$. Whilst some plants are fairly robust, none falls within the size range generally accepted for ssp. giganteus, which is confined to the afromontane region of East Africa. However, as pointed out by Arnell (1956) and Vanden Berghen (1965), intermediate forms between the subspecies also occur. [MJW]

*Cryptochila grandiflora (Lindenb. \& Gottsche) Grolle South of Nandiwo, 15 ${ }^{\circ} 53$ 'S $35^{\circ} 38^{\prime} \mathrm{E}$, damp rocks just above water level, stream, 2150 m, Hodgetts 2193a, det. J. Váňa. Apparently very local, with African records otherwise only from South Africa, Madagascar and Réunion.
Gottschelia schizopleura (Spruce) Grolle Fairly widespread on Mulanje Mt., and locally abundant in pure 'mats', recorded from the Lichenya Plateau, Upper Ruo Valley, Chinzama, Thuchila, and the path from Chinzama to Thuchila, and especially prominent in open areas on the plateau grasslands in the Minunu area, 1800-2120 m, 1926 June 1991 . Mainly on sandy or gritty, welldrained soil in open areas (fire-breaks, pathsides, banks), but sometimes of peaty substrates or on humus over rock. Perianths were rare in the material collected on these dates. Porley 127a, 234a; Wigginton 1263a; Hodgetts 2108b, 2114a, 2126e, 2143b, 2165d, 2166d, 2185f, 2194b, 2335d, 2409c, 2411b, 2419a; Kungu 3049b, 3136a; Magombo 4107a, 4153a, 4196a, 4205a, 4315a; O'Shea 7178a, 7435a, 7438b; Longton $8151 a, 8178 a, 8205 a, 8365 a, 8481 a$. The only other African records of this conspicuous species are from Tanzania, Madagascar and Réunion.

Jamesoniella purpurascens Steph. Quite widespread on Mulanje Mt., with records from Lichenya, Little Lujeri valley, Minunu, Ruo Gorge, Thuchila, and along the Chinzama to Sombani path, 1200-2180 m, 19-26 June 1991. Habitats varied, in shaded and open sites: on sandy, gritty or peaty soil on banks and damp path-sides, boulders, rotting wood, the base and trunk of living trees ( 2 colls.) and amongst Sphagnum on wet banks; some collections with perianths. Porley 245d; Wigginton 1254a (det. R. Grolle), 1258b; Hodgetts 2073d (det. J. Váňa), 2420b; Magombo 4115a; O'Shea 7176a, 7308a, 7313a; Longton 8037a, 8134a, 8145a, 8471a, $8497 a$. In Africa, otherwise recorded only in D.R. Congo, Tanzania, Zambia, South Africa, Madagascar, Mauritius and Réunion.

Jungermannia borgenii Gottsche Many collections of Jungermannia were made during the BBS expedition, but J. borgenii is the only species identified thus far. Found across the plateau and in the upper parts of valleys, including Chinzama, Lichenya, Minunu, Ruo, Thuchila, and the slopes of Chagaru and Sapitwa, 1780-2280, 20-28 June 1991. On sandy or gritty alluvium by montane springs, on wet peat in crevices, on damp, sandy soil in hollows and on 
banks in bared ground, and sometimes on rocks. Variable in size. Wigginton 1287a, 1306a, 1309b, 1324a, 1324b; Hodgetts 2114a, 2139a, $2140 a, 2145 a, 2166 a, 2307 a, 2314 a, 2418 a$, $2421 a, 2488 a, 2525 a$, all det. J. Váňa. Collections from other participants have not yet been studied. Also recorded from the Zomba plateau. Widespread in tropical and southern Africa, and East African islands.

*Notoscyphus lutescens (Lehm. \& Lindenb.) Mitt. Widespread on the Mulanje Mt. plateau, with collections from Lichenya, Malosa pools, Nandiwo and Nandalanda, Ruo valley, Thuchila, by paths from Lichenya to Chambe, and between Thuchila and Lukhulezi, 1720-2220 m, 19-28 June 1991. On sandy, loamy or peaty soil on banks, paths and tracks, riverbanks, on dry and moist granitic and sandstone rocks. Associates include, for example, Fissidens plumosus, Arachniopsis diacantha, Calypogeia spp. and Telaranea nematodes on peats; Symphyogyna spp., Gottschelia schizopleura, Jensenia spinosa, Ditrichum sp. on sandy substrates. Porley $140 b$; Wigginton 1203b, 1282a, 1283a, 1385a, 1599a, 1630c, 1633a, 1635b; Hodgetts 2145d, 2166c, 2197a; Magombo 4109a, 4233a, 4234a; Kathumba 5034a; Russell 6124a; O'Shea 7442a; Longton 8203b, 8205b. In Africa, there are records only from Cameroon, Rwanda, Burundi, D.R. Congo, South Africa and the Mascarenes.

*Tetralophozia cavallii (Gola) Ván̆a Slopes of Sapitwa, $15^{\circ} 56^{\prime} S 35^{\circ} 34^{\prime} \mathrm{E}$, on rock in boulder field in Erica arborea zone, with Riccardia sp., Campylopus sp., 2770-2900 m, 25 June 1991, Porley 250a, Hodgetts 2445d (det J. Váňa), Magombo 4309b. Mountains of East Africa, and a doubtful record from Zimbabwe.

*Tritomaria exsecta (Schmidel ex Schrad.) Schiffn. ex Loeske Thuchila to Chambe path, $15^{\circ} 55^{\prime} \mathrm{S} 35^{\circ} 34^{\prime} \mathrm{E}$, damp shaded earth bank, with Leptoscyphus infuscatus, Jungermannia borgenii, Lophocolea sp., 2220 m, 25 June 1991, Porley 261a. Sapitwa, $15^{\circ} 56^{\prime}$ 'S 35 35'E, on peat under rock, 2940 m, 25 June 1991, Hodgetts 2443d. Chinzama, $15^{\circ} 53^{\prime} \mathrm{S} 35^{\circ} 39^{\prime} \mathrm{E}$, on rotting tree in forest patch, with Lophocolea concreta, 2180 m, 22 June 1991, O'Shea M7314b. A mainly holarctic species, disjunct in Africa, with records from Ethiopia, Rwanda, South Africa, Tanzania and Uganda.

\section{LUNULARIACEAE}

Lunularia cruciata (L.) Dumort. ex Lindb. Chambe Basin, $15^{\circ} 53^{\prime} \mathrm{S} 35^{\circ} 32^{\prime} \mathrm{E}$, on shaded boulder in stream, $1900 \mathrm{~m}, 25$ June 1991, Longton $8402 a$. Chinzama to Sombani path, $15^{\circ} 53$ 'S $35^{\circ} 39^{\prime} \mathrm{E}$, on shaded humus-rich stream bank, 2180 m, 22 June 1991, O'Shea 7296a, both det. H. Bischler. There is also a record from the Zomba plateau. Eastern to southern Africa.

\section{MARCHANTIACEAE}

Marchantia pappeana Lehm. Chambe Basin, $15^{\circ} 53^{\prime} \mathrm{S} 35^{\circ} 32^{\prime} \mathrm{E}$, on soil by stream in Cupressus plantation, 1900 m, 25 June 1991, Kathumba $5135 a$. The Crater, near Muloza river, $16^{\circ} 1^{\prime} \mathrm{S}$ $35^{\circ} 32^{\prime} \mathrm{E}$, on boulder in shaded gully in Newtonia forest, 885 m, 30 June 1991, Longton 8636a. Both collections det. H. Bischler. Previously recorded, as $M$. parviloba, from the Zomba plateau. Widespread in Africa: Cape Verde Islands, West and East tropical Africa south to South Africa.

\section{MASTIGOPHORACEAE}

*Mastigophora diclados (Brid.) Nees Lower Ruo Gorge (Minunu path), 1557'S 35³9'E, on buttress of old forest tree, with Chandonanthus hirtellus, Herbertus sp., Ceratolejeunea jungneri, 1020-1050 m, 18 June 1991, Porley 96a; Hodgetts 2043b; Wigginton 1186a; O'Shea 7071a. All collections det. or conf. M.J. Wigginton. Local in tropical west and East Africa, and the East African islands.

\section{PLAGIOCHILACEAE}

The BBS collections of Plagiochila have been identified by N.G. Hodgetts, unless stated otherwise. Representative collections of most species have been confirmed by T. Pócs.

*Plagiochila angustitexta Steph. Collections from Chambe Plateau, Chisongoli Forest, Lujeri Forest and by Little Lujeri River, Muluzi River and the Ruo Gorge, 1120-1880 m, 16-20 June 
1991. Found in shaded and open sites, on trunks, branches and twigs of mature forest trees (including the spongy bark of Widdringtonia cupressoides), saplings and shrubs. Porley $23 a$, 45a; Wigginton 1019a, 1022b, 1026d, 1027d, 1036b, 1096b; Hodgetts 2094a, 2208b, 2216a; Kungu 3023a, 3024a; Magombo 4016a; O'Shea 7046b, 7088c. Chambe Basin, $15^{\circ} 53^{\prime} \mathrm{S} 35^{\circ} 32^{\prime} \mathrm{E}$, rocks on side of dry gully, $1880 \mathrm{~m}, 7$ August 1993, Stevenson CRS173. Otherwise recorded only from Tanzania.

Plagiochila barteri Mitt. Found widely on Mulanje Mt., with collections from Chisongoli, Lichenya, Lujeri Forest and River, Muluzi river, Ruo Gorge, Thuchila, path from Ruo Gorge to Minunu Hut, Chapaluka to Chambe path, 10201980 m, 17-28 June 1991. Most collections from the trunks (including buttresses) of forest trees, but also on upper branches and lianes. There were 3 collections from rock and one from a log. Wigginton 1184a, 1711c; Hodgetts 2006c, 2042i, $2077 a, 2134 a, 2223 a, 2235 a, 2237 a, 2245 b$; Magombo 4045a, 4261a; O'Shea 7062a, 7072a, 7096a, 7488c; Longton 8044a, 8082a, 8474a. Chapaluka path, $15^{\circ} 55^{\prime} \mathrm{S} 35^{\circ} 32^{\prime} \mathrm{E}$, epiphytic on a liane, 1420 m, 7 August 1993, Stevenson CRS138. Tropical and southern Africa, including East African islands.

*Plagiochila cambuena Steph. Thuchila to Chambe path, $15^{\circ} 55^{\prime} \mathrm{S} 35^{\circ} 33^{\prime} \mathrm{E}$, vertical face of shaded rock by path, $2020 \mathrm{~m}, 24$ June 1991, Wigginton 1515a, conf. N.G. Hodgetts. The other African records are from Tanzania and Madagascar.

*Plagiochila effusa Steph. Slopes of Chagaru, $15^{\circ} 53^{\prime} \mathrm{S} 35^{\circ} 40^{\prime} \mathrm{E}$, on a tree branch and a rock in ravine of mountain stream, $2320 \mathrm{~m}, 21$ June 1991, Wigginton 1351a, 1355a. Near Forest Dept. staff quarters, Sombani Basin, $15^{\circ} 53^{\prime} \mathrm{S} 35^{\circ} 42^{\prime} \mathrm{E}$, on tree bark in open woodland, $2080 \mathrm{~m}, 21$ June 1991, O’Shea 7230b. Chambe Basin, 1553'S $35^{\circ} 32^{\prime} \mathrm{E}$, shaded sandstone rock-face in forest, 1900 m, 25 June 1991, Longton 8417a. Recorded also in Equatorial Guinea, Bioko, Angola, Kenya, Tanzania and Uganda.

*Plagiochila exigua (Taylor) Taylor Slopes of
Namasile, $15^{\circ} 53^{\prime} \mathrm{S} 35^{\circ} 40^{\prime} \mathrm{E}$, trunk of tree in ravine of mountain stream, $2320 \mathrm{~m}, 21$ June 1991, Wigginton 1346a. Upper Ruo Gorge, $15^{\circ} 55^{\prime} \mathrm{S}$ $35^{\circ} 38^{\prime} \mathrm{E}$, on tree trunk by forest path, $1880 \mathrm{~m}$, 20 June 1991, Hodgetts 2086f, det. T. Pócs. Sapitwa, $15^{\circ} 56^{\prime} \mathrm{S} 35^{\circ} 35^{\prime} \mathrm{E}$, epiphytic on Erica arborea on summit ridge, 2900 m, 25 June 1991, Hodgetts $2482 a$, det. T. Pócs. Tropical East, and southern Africa, Réunion.

Plagiochila fusifera Taylor The Crater: Muloza River, Chinzama to Sombani path, Muluzi river, Ruo Gorge, tributary of Thuchila River, Thuchila Plateau, Slopes of Namasile, 885-2320 m, 16-30 June 1991. On trunks, branches and twigs of living trees, on dead wood, and on rock. Wigginton 1353a; Hodgetts 2003a, 2039b, $2348 b$ (det. T. Pócs); O’Shea 7081c; Longton 8283a, 8646a. Widespread in tropical West and East Africa.

Plagiochila heterostipa Steph. With 49 collections, this was the most collected species during the BBS Expedition: Chinzama to Sombani, Chisongoli, Lichenya, Minunu, Ruo Gorge, Sombani basin, Thuchila, slopes of Namasile and Dzole, 740-2320 m, 16-30 June 1991. Found on roots, base, trunk, branches and thin twigs of forest trees; sometimes on rock and occasionally on rotting logs. Porley (1), Wigginton (5), Hodgetts (9), Kungu (3), Kathumba (2), Russell (2), O’Shea (23), Longton (4). Also from the Zomba plateau. Quite widespread in east and southern Africa,

*Plagiochila integerrima Steph. This common species is almost certainly under-represented in collections, which are from Chisongoli, Nessa path, Lichenya plateau, Lujeri Gorge, Ruo Gorge and The Crater, 760-1800 m, 16-30 June 1991. Apart from one collection from a rotting tree trunk in riverine forest, all collections were from shaded, damp rocks on the forest floor or by streams, sometimes in places subject to inundation. Porley 269a; Wigginton 1149a, 1188a; Hodgetts 2044c, 2225a, 2654a, 2689b, 2690e; Kathumba 5181a, 5921a; Russell 6028b; O'Shea 7002a, 7552a, 7555b, 7567b; Longton $8013 a$. Widespread in tropical Africa south to Zimbabwe; East African islands. [NGH] 
Plagiochila kiaeri Gottsche sens. lat. Lichenya Path: tributary of Likhubula River, $15^{\circ} 56^{\prime} \mathrm{S}$ $35^{\circ} 31^{\prime} \mathrm{E}$, on rocks by river, $1200 \mathrm{~m}, 29$ June 1991, Hodgetts 2627a, conf. T. Pócs. Chinzama to Sombani path, $15^{\circ} 53^{\prime} \mathrm{S} 35^{\circ} 39^{\prime} \mathrm{E}$, rotting $\log$ in isolated Widdringtonia stand, $2180 \mathrm{~m}, 22$ June 1991, O’Shea 7300c. Chambe Basin, $15^{\circ} 53^{\prime} \mathrm{S}$ $35^{\circ} 32^{\prime} \mathrm{E}$, on boulder in stream in broad-leaved evergreen forest, 1900 m, 25 June 1991, Longton 8403a. East tropical Africa, and Angola.

Plagiochila kiaeri var. myriocarpa Chinzama to Sombani, Chisongoli, Lujeri, Ruo Gorge, Thuchila and S. of Nandiwo, 1050-2180 m, 1726 June 1991. Mainly on twigs, branches and trunks of trees and shrubs in open forest, sometimes on deadwood on the forest floor. Porley 45b, 92a; Hodgetts 2379b; Magombo 4031a; Kathumba 5007a, 5009a, 5011a; Russell 6047a; O'Shea 7046a, 7050a, 7057a, 7086c, 7226b, 7228b, 7232a, 7246b, 7286a; Longton $8475 b$. East Africa from Ethiopia to Zambia.

Plagiochila lastii Mitt. This common species is well distributed throughout the Mulanje massif, the 48 collections coming from Chambe, Chinzama, Chisongoli, Lichenya plateau and Nessa path, Lujeri, Ruo Valley, Sombani, Thuchila, slopes of Namasile, path from Likhubula to Chambe, 1200-2180 m, 16-28 June 1991. Mostly from the trunks, branches and twigs of forest trees and shrubs, and rarely from rotting wood. One collection was from a sandstone boulder in a Cupressus plantation, and one from bamboo. Porley (3), Wigginton (7), Hodgetts (16), Kungu (4), Magombo (2), Russell (1), O'Shea (9), Longton (4); Stevenson (2) (7 August 1993). Tropical East, and southern Africa.

* Plagiochila pectinata (Willd. ex F.Weber) Lindenb. Fairly widespread in Mulanje Mt., with collections from Chisongoli, Lichenya plateau and Nessa path, Minunu, Ruo Valley, Sombani, and S. of Nandiwo, 1260-2130 m, 16-28 June 1991. On roots and trunks of forest trees, on stems of shrubs, on rotting logs and other deadwood, and on damp, shaded rocks (including seepage areas). Porley 103b, 187a; Wigginton 1024b,
$1037 d, 1052 b, 1250 b, 1693 a$; Hodgetts 2007b, 2095b, 2143i, 2538a, 2541a, 2552d, 2556a; Kathumba 5005a; Russell 6077a, 6126a; O'Shea 7132a. Tropical Africa, including the East African islands.

Plagiochila squamulosa Mitt. sens. lat. Lichenya River, $15^{\circ} 58^{\prime}$ S $35^{\circ} 33^{\prime} \mathrm{E}$, on soil bank by path, with Jungermannia and Cephalozia, 1760 m, 27 June 1991, Wigginton 1623a. Near Forest Dept. staff quarters, Sombani Basin, on tree bark in open woodland, $15^{\circ} 53^{\prime} \mathrm{S} 35^{\circ} 42^{\prime} \mathrm{E}$, 2080 m, 21 June 1991, O’Shea 7227e. Tropical West and East Africa.

Plagiochila squamulosa var. crispulo-caudata (Gottsche) Vanden Berghen Probably undercollected: Chinzama to Sombani, Lichenya plateau, Madzeka path, Thuchila plateau, and by the Chapaluka path to Chambe, 965-1980 m, 1628 June 1991. Found on trunks and twigs of living trees, on Hypericum bushes, on fallen wood, and on shaded rock. Porley $3 a$; Wigginton $1027 b$, 1424c; Hodgetts $2348 f$ (det. T. Pócs); O'Shea 7013a, 7284a, 7517c, 7518a, 7536a; Stevenson CRS141, CRS161, CRS207 (7 August 1993). Other Malawi records from Blantyre, Thyolo and Zomba Districts. Cameroon, tropical East, and southern Africa, Madagascar and Réunion.

Plagiochila squamulosa var. sinuosa (Mitt.) Vanden Berghen Collecting localities include Chambe, Chapaluka path, Lichenya, Likhubula River, Madzeka path (Ruo valley), Sombani and The Crater, 920-2070 m, 16-30 June 1991. Found on the trunks, branches and twigs of living trees, and on rocks. Wigginton 1548a, 1743a; Hodgetts 2016a, 2667a; Kungu 3216a; Magombo 4333a; O'Shea 7014d; Longton 8254a; Stevenson CRS145, CRS152 (7 August 1993). RUMPHI: Nyika NP, $10^{\circ} \mathrm{S} 33^{\circ} \mathrm{E}$, epiphytic on garden shrub, 2245 m, 30 July 1993, Stevenson CRS051. In Malawi, also from Zomba plateau. Tropical East Africa and East African islands.

Plagiochila strictifolia Steph. Chisongoli Forest, $16^{\circ} 0$ 'S $35^{\circ} 43^{\prime} \mathrm{E}$, on trunk of forest tree, $1625 \mathrm{~m}$, 17 June 1991, Hodgetts 2205c, 2209a. Thuchila plateau, $15^{\circ} 53^{\prime} \mathrm{S} 35^{\circ} 36^{\prime} \mathrm{E}$, on dead twigs fallen 
from canopy, 1890 m, 22 June 1991, Hodgetts 2348a. Chambe to Lichenya path, $15^{\circ} 55^{\prime} \mathrm{S}$ $35^{\circ} 33^{\prime} \mathrm{E}$, trunk of forest tree, $1980 \mathrm{~m}$, 26 June 1991, Hodgetts 2490a. Nessa path, Lichenya plateau, $16^{\circ} 1^{\prime} \mathrm{S} 35^{\circ} 32^{\prime} \mathrm{E}$, on twigs of forest shrub, 1800 m, 27 June 1991, Hodgetts 2542a. Ruo basin, $1 \mathrm{~km} \mathrm{~S}$ of Nandiwo peak, $15^{\circ} 53^{\prime} \mathrm{S}$ $35^{\circ} 38^{\prime} \mathrm{E}$, on tree roots in montane Podocarpus forest, 2130 m, 23 June 1991, Russell 6070a. Tropical West and East Africa.

Plagiochila terebrans Nees \& Mont. ex Lindenb. Nessa path, Lichenya plateau, $15^{\circ} 59^{\prime} \mathrm{S}$ $35^{\circ} 34^{\prime} \mathrm{E}$, foliicolous - upper surface of older leaves of forest shrub, 1800 m, 27 June 1991, Porley 281b. Valley W of Minunu hut, 1555'S $35^{\circ} 38^{\prime}$ E, on shaded soil on rock by stream, 1990 m, 19 June 1991, Kungu 3034a. Near Forestry Dept. offices, Sombani basin, $15^{\circ} 53^{\prime} \mathrm{S} 35^{\circ} 42^{\prime} \mathrm{E}$, from tree trunk and fallen tree branch, $2080 \mathrm{~m}$, 21 June 1991, O'Shea 7253c, 7254d. Also from Zomba Mt. Tropical and southern Africa.

\section{RADULACEAE}

Most of the BBS collections of Radula have been identified or confirmed by N.G. Hodgetts, unless stated otherwise. Representative collections of most species have been identified or confirmed by K. Yamada.

*Radula appressa Mitt. Apparently local on Mulanje Mt., with records from only three areas. By Muluzi River, Chisongoli, 16''ㅇ 3543'E, trunk of tree, $1230 \mathrm{~m}, 16$ June 1991, Wigginton 1024a. Chisongoli Forest, $16^{\circ} 0^{\prime} \mathrm{S} 35^{\circ} 42^{\prime} \mathrm{E}$, tree trunk and twigs fallen from forest canopy, 1625 m, 17 June 1991, Porley 34a; Wigginton 1037a; Hodgetts 2207d, 2209e, 2222a, 2223i; Magombo $4024 a$. Minunu path, Ruo valley, $15^{\circ} 57^{\prime} \mathrm{S}$ $35^{\circ} 39^{\prime} \mathrm{E}$, on riverside rock, $1100 \mathrm{~m}, 19$ June 1991, Hodgetts 2046h. By Mulozi river, near The Crater, $16^{\circ} 1^{\prime} \mathrm{S} 35^{\circ} 32^{\prime} \mathrm{E}$, trunk of tree, $920 \mathrm{~m}, 30$ June 1991, Longton 8658a. Tropical and southern Africa, and East African islands.

Radula boryana (F.Weber) Nees The commonest Radula on Mulanje Mt., and a conspicuous epiphyte on forest trees and shrubs (occasionally foliicolous), and on shaded rocks. Localities include Chambe, Chisongoli, Lujeri,
Nessa path, Lichenya plateau, Minunu, Ruo valley, The Crater and Thuchila, 910-2120 m, 16-30 June 1991. Porley (4), Wigginton (9), Hodgetts (30), Kungu (3), Magombo (4), O’Shea (7), Longton (3). Previous Malawi records are from Blantyre, Mulanje and Zomba Districts. Widespread in tropical and southern Africa.

*Radula comorensis Steph. Chisongoli Forest, $16^{\circ} 0^{\prime} \mathrm{S} 35^{\circ} 43^{\prime} \mathrm{E}$, trunk of forest trees, and vertical face of boulder, 1625-1630 m, 17 June 1991, Porley 37a; Wigginton 1047a; Hodgetts 2212a, $2213 a$. Nessa path, Lichenya plateau, foliicolous on forest shrub, $1820 \mathrm{~m}$, 27 June 1991, Hodgetts 2554ff. Sombani, $15^{\circ} 53^{\prime} \mathrm{S} 35^{\circ} 42^{\prime} \mathrm{E}$, on forest tree, 2000 m, 21 June 1991, Kathumba 5006a. Chambe basin, under large rock by stream, 1900 m, 25 June 1991, Kathumba 5128a. Little Lujeri Gorge, $15^{\circ} 58^{\prime} \mathrm{S} 35^{\circ} 37^{\prime} \mathrm{E}$, on boulders near river in forest, 1200 m, 17 June 1991, Russell $6022 b$. D.R. Congo, Rwanda, Uganda, Lesotho, Mauritius, Réunion and the Comoro islands.

Radula holstiana Steph. Widespread on Mulanje Mt., with collections from Chambe basin, Muluzi River Chisongoli, Lichenya, Lujeri, Ruo valley, Sombani, The Crater, Thuchila and the slopes of Namasile, 920-2320 m, 17-30 June 1991. Most frequently on the trunks, branches and small twigs of forest trees and shrubs, usually in mixed bryophyte mats; sometimes on rock and occasionally a foliicolous species. Porley (3); Wigginton (3); Hodgetts (15); Magombo (1); Russell (1); O'Shea (7); Longton (3). Also recorded from Zomba Mt. Widespread in tropical and southern Africa.

*Radula lindenbergiana Gottsche ex. Hartm. f. Rare or overlooked on Mulanje Mt. Slopes of Namasile, 1553'S 3540'E, 2320 m, 21 June 1991, Wigginton 1349a, det. K. Yamada. There are African records only from the Cape Verde islands, Tanzania, Zimbabwe, Lesotho and South Africa.

*Radula madagascariensis Gottsche Local or overlooked, with records from only three localities. Chisongoli, $16^{\circ} 0^{\prime} \mathrm{S} 35^{\circ} 43^{\prime} \mathrm{E}$, thin stem of sapling in forest, $1230 \mathrm{~m}, 16$ June 1991, Wigginton 1026a, det. K. Yamada. Lower Ruo 
Gorge, $15^{\circ} 57^{\prime} \mathrm{S} 35^{\circ} 39^{\prime} \mathrm{E}$, buttress of forest tree, 1000 m, 19 June 1991, Wigginton 1170c, 1171a. Upper Ruo Gorge, $15^{\circ} 55^{\prime} \mathrm{S} 35^{\circ} 36^{\prime} \mathrm{E}$, spongy bark at base of forest tree, $1850-1880 \mathrm{~m}, 20$ June 1991, Wigginton 1235a; Hodgetts 2073i. Thuchila plateau, $15^{\circ} 53^{\prime} \mathrm{S} 35^{\circ} 36^{\prime} \mathrm{E}$, trunk and branch of forest tree, 1720-1750 m, 23 June 1991, Hodgetts $2373 a, 2375 a, 2381 b$, det. K. Yamada. The only other mainland records are from Tanzania; also in Madagascar, Mauritius and Réunion.

*Radula quadrata Gottsche Lichenya River, $15^{\circ} 58^{\prime} \mathrm{S} 35^{\circ} 33^{\prime} \mathrm{E}$, tree bark and twigs in riverine forest, 1720 m, 27 June 1991, Wigginton 1659a; Kungu 3338a. Nessa path, Lichenya Plateau, $15^{\circ} 59^{\prime} \mathrm{S} 35^{\circ} 33^{\prime} \mathrm{E}$, foliicolous on forest shrubs, 1800 m, 27 June 1991, Hodgetts 2567b, 2574b. CCAP hut, Lichenya plateau, tree bark, $1980 \mathrm{~m}$, 26 June 1991, Magombo 4336a. Lichenya Rest House, $15^{\circ} 58^{\prime} \mathrm{S} 35^{\circ} 33^{\prime} \mathrm{E}$, trunk of Cupressus macrocarpa in open woodland, 1840, 27 June 1991, Longton 8542a, 8544a. Cameroon; East and southern Africa; East African islands.

*Radula stenocalyx Mont. Nessa path, Lichenya plateau, $15^{\circ} 59^{\prime} \mathrm{S} 35^{\circ} 34^{\prime} \mathrm{E}$, foliicolous on forest shrub, 27 June 1991, Porley 287u, det. K. Yamada. Tributary of Thuchila River, Thuchila Plateau, $15^{\circ} 53$ 'S $35^{\circ} 36$ ' E, foliicolous on forest shrub, 1760 m, 23 June 1991, Wigginton 1498b, det. K. Yamada. Tropical and southern Africa.

Radula stipatiflora Steph. Widespread but rather few collections: Chambe basin, Chisongoli, Lichenya, Lujeri, Minunu, Ruo Gorge, Sombani and the slopes of Namasile, 1200-2320 m, 17-27 June 1991. Base, trunk, branches and small twigs of forest trees, tree-ferns and shrubs (9 colls.); shaded rock (2 colls.); foliicolous (1 coll.). Wigginton 1349b, 1537a, 1650a; Hodgetts 2073j, 2255c, 2522f; Kungu 3039a, 3326a; Kathumba 5006b, 5095a; O’Shea 7054c; Longton 8543a. Other Malawi records are from the Zomba plateau. Bioko, East and southern Africa, and Réunion.

*Radula voluta Taylor ex Gottsche et al. Recorded only at the higher altitudes on Mulanje Mt.: Chambe to Lichenya path, Upper Ruo valley, Sombani basin, Thuchila, between Chinzama and
Thuchila, and the slopes of Namasile. Mainly from tree roots, trunks and branches, but also on shaded rocks, often creeping over other bryophytes, 1880-2320 m, 21-26 June 1991. Porley 198a; Wigginton 1353d, 1353f; Hodgetts 2357a, 2490b; Kungu 2357a; Magombo 4260b; Russell 6036d; O'Shea 7224b; Longton 8217a, 8229a. Bioko, East and southern Africa, and Réunion.

\section{RICCIACEAE}

Riccia lanceolata Steph. Chinzama to Sombani path, $15^{\circ} 53^{\prime} \mathrm{S} 35^{\circ} 39^{\prime} \mathrm{E}$, rotting $\log$ in Widdringtonia stand, 2180 m, 22 June 1991, O'Shea 7321c, det. S.M. Perold. Several collections from Malawi were published in Perold (1995), including another collected during the BBS expedition (Porley 67a). Tropical West and East Africa south to Zambia.

\section{TARGIONIACEAE}

Targionia hypophylla L. Chisongoli, $16^{\circ} 1^{\prime} \mathrm{S}$ $35^{\circ} 43^{\prime} \mathrm{E}$, on damp boulder by path, $1200 \mathrm{~m}, 17$ June 1991, Porley 65a, det. R.D. Porley. By Mulozi River, near The Crater, $16^{\circ} 1^{\prime} \mathrm{S} 35^{\circ} 32^{\prime} \mathrm{E}$, sandstone boulder at edge of Newtonia forest, 865 m, 30 June 1991, Longton 8609a, det T. Pócs. Also recorded in Malawi from Limbe and Ndirande, Blantyre district. Widespread in Africa.

\section{MOSSES}

\section{ANDREAEACEAE}

All specimens identified or confirmed by N.G. Hodgetts or B.M. Murray unless otherwise stated.

*Andreaea acutifolia var. acutifolia Hook. f. \& Wils. Sapitwa, $15^{\circ} 57^{\prime}$ S $35^{\circ} 35^{\prime}$ E, granite rock outcrop in montane grassland ledge on south side of mountain, $2800 \mathrm{~m}$. 25 June 1991, Porley 257a; loc. cit., rock in grass in shade of cliff below summit, 2980 m, 25 June 1991, Hodgetts 2464d. Associates: Andreaea obovata, A. subulata, Racomitrium alare and Herbertus sp. Known also from Lesotho and South Africa, but mainly from 
areas south of Africa.

*Andreaea borbonica Besch. Sapitwa, 1557'S $35^{\circ} 35^{\prime} \mathrm{E}$, shaded top of large rock in boulderfield on north side of mountain, $2770 \mathrm{~m}$, 25 June 1991, Porley 249a; shaded granite rock face under overhanging slabs at summit, $3000 \mathrm{~m}, 25$ June 1991, Porley 252a; under shady overhang at summit, $3000 \mathrm{~m}$, 25 June 1991, Hodgetts $2454 a$; by pool under rock just below summit, just above water level, 2990 m, 25 June 1991, Hodgetts 2456a. The last two specimens listed are approaching A. rupestris. Associates observed were Campylopus flaccidus, Racomitrium alare, Anastrophyllum auritum and Chandonanthus birmensis. This species may prove to be identical with A. rupestris or A. alpestris. Known previously only from Réunion. [NGH]

*Andreaea nitida Hook.f. \& Wils. Sapitwa, $15^{\circ} 57^{\prime} \mathrm{S} 35^{\circ} 35^{\prime} \mathrm{E}$, very cold shaded ledge on frost-heaved skeletal soil on south-facing aspect near summit, with Rhacocarpus purpurascens and Campylopus praetermissus, $2865 \mathrm{~m}, 25$ June 1991, Porley 260a (det. R.D. Porley, conf. B.M. Murray); clump in seasonal rill just below summit (Hodgetts 2470c), ice-covered rock below summit (Hodgetts 2477b), frozen in gravelly soil in ice patch below summit (Hodgetts 2478a), all at $2980 \mathrm{~m}, 25$ June 1991. Other associates: Adelanthus lindenbergianus and Campylopus dicranoides. Previously recorded in Africa only from South Africa (Cape).

*Andreaea obovata Thed. Tributary of Thuchila River, at Red Route Shelter, 15 ${ }^{\circ} 56^{\prime}$ 'S $35^{\circ} 35^{\prime} \mathrm{E}$, on granitic exposed bed of seasonal stream at base of Sapitwa, with A. subulata, 2220 m, 24 June 1991, Porley $240 b$ (det. R.D. Porley); Sapitwa, $15^{\circ} 57^{\prime} \mathrm{S} 35^{\circ} 35^{\prime} \mathrm{E}$, ledge in granitic rock outcrop in montane grassland, south side of mountain, 2800 m, 25 June 1991, Porley $257 b$ (det R.D. Porley); loc. cit., rocks in shade of cliff below summit, 2980 m, 25 June 1991, Hodgetts 2464a, 2468a; near summit of False West Peak, $15^{\circ} 57^{\prime} \mathrm{S}$ $35^{\circ} 34^{\prime}$ E, exposed granitic slab, $2600 \mathrm{~m}$, 28 June 1991, Longton $8563 a$ (det. R.E. Longton). Associates recorded: Racomitrium alare, Andreaea acutifolia and A. subulata. Known from D.R. Congo, Rwanda, Tanzania and Kenya.
*Andreaea subulata Harv. Thirteen collections from Sapitwa and False West Peak, on shaded or exposed rocks, often subject to periodic inundation, from 2140-3000 m; Porley 240a, 256a, $257 a$ (all det. R.D. Porley); Hodgetts $2424 e, 2426 a, 2433 a, 2451 a, 2460 a, 2464 c$, 2467a, 2469a; O'Shea 7529a (det. B.J. O'Shea); Longton $8563 \mathrm{~b}$. Other African records are from Uganda, Madagascar and South Africa (Cape).

\section{ANOMODONTACEAE}

Herpetineuron toccoae (Sull. \& Lesq.) Cardot Gorge of Mulozi River, below Hutson's house, $16^{\circ} 2^{\prime} \mathrm{S} 35^{\circ} 43^{\prime} \mathrm{E}$, shaded vertical face of boulder in ravine, 740 m, 18 June 1991, Hodgetts $2285 a$ (det. A. Touw); loc. cit., shaded rocks by river, 760 m, 18 June 1991, Wigginton 1144d (det. A. Touw); Likhubula River, $15^{\circ} 56^{\prime} \mathrm{S} 35^{\circ} 31^{\prime} \mathrm{E}$, alluvium on rocks by river, $1000 \mathrm{~m}, 30$ June 1991 , Wigginton 1745a, 1749 a (det. M.J. Wigginton). Previously known in Malawi from three collections by A.C. Crundwell in 1969 at Soche and Chichiri, and recorded also from western and eastern Africa, and South Africa. [BJO]

\section{ARCHIDIACEAE}

*Archidium amplexicaule Müll.Hal. Thuchila to Chambe path, $15^{\circ} 55^{\prime} \mathrm{S} 35^{\circ} 34^{\prime} \mathrm{E}$, compacted soil in crevice of rock along path, associated with Pleuridium sp., Aongstroemia julacea, Gongylanthus ericetorum and Campylopus pilifer, 2220 m, 26 June 1991, Porley 262c; det. I.G. Stone. Otherwise recorded only from South Africa (Cape).

*Archidium microthecium Dixon \& P.de la Varde Path from Thuchila Hut to Lukhulezi, $15^{\circ} 53^{\prime} \mathrm{S} 35^{\circ} 37^{\prime} \mathrm{E}$, sandy soil in open Brachystegia woodland, 1800 m, 23 June 1991, Longton $8337 a$; det. I.G. Stone. Other records are from Tanzania, Zambia, Namibia and South Africa.

\section{BRYACEAE}

All collections identified or confirmed by A.C. Crundwell unless otherwise stated.

Brachymenium acuminatum Harv. Various 
localities across the plateau, always on soil by paths, on boulders, in grassland and on stream banks, 890-2260 m (only two collections below $1200 \mathrm{~m}$ ); Wigginton 1510a, 1738a; Hodgetts $2278 c, 2624 a$ (both det. R.E. Magill); Magombo 4182a; O'Shea 7366a, 7392a, (both det. B.J. O'Shea); Longton 8186a, 8339a, 8457a, 8598c; R.J. Wolton W06a. Widespread throughout tropical and southern Africa.

Brachymenium angolense (Welw. \& Duby) A.Jaeger Lichenya to Likhubula path, $15^{\circ} 56^{\prime} \mathrm{S}$ $35^{\circ} 31^{\prime} \mathrm{E}$, tree trunk in open Brachystegia woodland, 1200 m, 29 June 1991, Wigginton $1735 \mathrm{~b}$. Reported only twice from Malawi, and from Angola and eastern and southern Africa.

*Brachymenium dicranoides (Hornsch.) A.Jaeger Lujeri Tea Estate, No. 3 Shed, 1559'S $35^{\circ} 39^{\prime} \mathrm{E}$, sides of a granitic and concrete culvert, 780 m, 18 June 1991, Longton 8103a. Known elsewhere only from Cape Province and Zimbabwe.

*Brachymenium eurychelium Besch. By Lichenya River, $15^{\circ} 59^{\prime} \mathrm{S} 35^{\circ} 33^{\prime}$ E, epiphytic on bamboo, 1720 m, 27 June 1991, Longton 8517a. New to mainland Africa: only previously known from Réunion, Mauritius and Rodriguez.

Brachymenium nepalense Hook. Madzeka Path, $15^{\circ} 58^{\prime} \mathrm{S} 35^{\circ} 40^{\prime} \mathrm{E}$, bark of Mangifera indica in open forest, $965 \mathrm{~m}, 16$ June 1991, O'Shea 7012a, 7021a; near Forest Department Staff Quarters, Sombani Basin, 1553'S 35 43'E, tree bark in open forest, $2080 \mathrm{~m}, 21$ June 1991 , $O$ 'Shea 7275 a. Recorded previously for Zomba Mt., but new for Mulanje. Known from West, East and southern Africa.

Bryum alpinum Huds. ex With. Found at various localities across the plateau, on rocks and once on soil, often by rivers, 1700-2230 m, Porley $153 a$ (det. R.D. Porley); Wigginton 1679a, 1739a (both det. M.J. Wigginton); Hodgetts 2126b, 2130b, 2168b, 2387a, 2424c, 2593a (all det. NGH); Kungu 3196a; O'Shea 7197a (det. B.J. O'Shea), 7496a; Longton 8206a, 8501a, 8456a. Two previous collections from Malawi (from Mulanje); widespread in east and southern Africa.
Bryum arachnoideum Müll.Hal. Two collections on the plateau, but the rest at the base or on the slopes of Mt. Mulanje, usually on rocks but also on soil, 850-2080 m, Wigginton 1739b; Magombo 4404a; O'Shea 7031b, 7263a, 7590a; Longton 8110a, 8342a, 8603a; R.J. Wolton $W 12 a$. The specimens collected at higher elevations were usually growing as more scattered stems amongst other bryophytes rather than in pure mats. Found throughout tropical Africa.

Bryum keniae Müll.Hal. Throughout the mountain, in shaded areas on boulders, soil and living and dead trees, 740-2130 m, Porley la, 73a; Hodgetts 2004a; Kungu 3053a, 3303a; Magombo 4103a; Russell 6054a, 6092a; O'Shea 7065a, 7098a, 7270a, 7403a, 7501a, 7589a; Longton 8072a, 8556a, 8560. Previously known in Malawi from both Mulanje and Zomba Plateaux. Mainly recorded from East and southern Africa, but also found in the west.

*Bryum torquescens Bruch ex De Not. Thuchila Hut, 1553'S 35 37'E, dry grassland, 2000 m, 24 June 1991, Longton 8377. From Sudan and Ethiopia southwards in eastern Africa, and in southern Africa.

Mielichhoferia bryoides (Harv.) Wijk \& Margad. Sapitwa, $15^{\circ} 57^{\prime} S$ 35 $35^{\prime}$ E, damp shaded soil between boulders in boulder field on N side of mountain, 2770 m, 25 June 1991, Porley $248 a$ (det. R.D. Porley). Previously known in Malawi only from a single collection on Nyika Plateau. Elsewhere in Africa only known from Zimbabwe and South Africa.

Pohlia baronii Wijk \& Margad. Eighteen collections from across the plateau, on rock, gravel and soil, 1700-2350 m; Porley (4), Hodgetts (1), Kathumba (1), Russell (2), O'Shea (9), Longton (2). New to Mulanje (previously known only from Zomba); from Kenya south to South Africa.

Pohlia elongata Hedw. Generally distributed across the plateau, usually on soil or rock but also on trees, and a sandbank in a stream, 1800-2890 
$\mathrm{mm}$, but mainly at the higher altitudes (several collections were from Sapitwa, the highest peak on the mountain, which rises to $3000 \mathrm{~m}$ ); Porley $160 a$ (det. R.D. Porley); Wigginton 1359c; Kungu 3068a, 3289a; Magombo 4225a, 4278a, 4296a, 4300a; O'Shea 7339c, 7393a, 7530a; Longton $8414 a, 8561 a, 8571 a$. A number of collections already made on Mulanje; elsewhere in Africa in the east and south.

Rhodobryum commersonii (Schwaegr.) Brid. Ruo Gorge, $15^{\circ} 56^{\prime} \mathrm{S} 35^{\circ} 39^{\prime} \mathrm{E}$, on thick litter on branch of tree at head of waterfall, $1830 \mathrm{~m}, 20$ June 1991, Porley 135a; Chinzama to Sombani track, in isolated Widdringtonia stand, 1553'S $35^{\circ} 39^{\prime} \mathrm{E}$, soil over granitic boulder by stream, 2180 m, 22 June 1991, Longton 8278a. Previously known from Malawi from one Mulanje collection, and found elsewhere in eastern and particularly southern Africa.

\section{CALYMPERACEAE}

All specimens identified by L.T. Ellis.

*Calymperes afzelii Sw. The Crater: Mulozi River, $16^{\circ} 1^{\prime} \mathrm{S} 35^{\circ} 32^{\prime} \mathrm{E}$, bark of Newtonia stump in shade, 885 m, 30 June 1991, Porley 328a; trunk of large tree by river, $920 \mathrm{~m}, 30$ June 1991, Longton $8657 b$, 8660b. Widespread in tropical Africa and East African islands.

Syrrhopodon asper Mitt. Near Lichenya R., $15^{\circ} 56^{\prime} \mathrm{S} 35^{\circ} 33^{\prime} \mathrm{E}$, on Widdringtonia in bamboo forest, 1750 m, 6 November 1981, Rammeloo $R 7209 b$; Ruo valley below Minunu Hut, $15^{\circ} 57^{\prime} \mathrm{S}$ 35³9'E, amongst Hymenophyllum, 1075 m, 19 June 1991, Porley 94h; Sombani Basin, near Forest Dept. Staff Quarters, 1553'S 3542'E, soil bank under ferns in open forest, $2080 \mathrm{~m}, 21$ June 1991, O'Shea 7244e; lower slopes of Dzole, $15^{\circ} 54^{\prime} \mathrm{S} 35^{\circ} 36^{\prime} \mathrm{E}$, on spongy bark of forest trees in forest patch, $2020 \mathrm{~m}, 24$ June 1991, Hodgetts 2405a; Lichenya Plateau, Nessa Path, 1559’S $35^{\circ} 34^{\prime} \mathrm{E}$, sloping, rotten, forest tree, $1800 \mathrm{~m}, 27$ June 1991, Hodgetts 2544b; The Crater, $16^{\circ} 1^{\prime} \mathrm{S}$ $35^{\circ} 32^{\prime}$ E, on rock by river, 900 m, 30 June 1991, Kathumba 5196a. Recorded in Gabon and in central and east Africa, south to Transvaal.

Syrrhopodon gardneri Hook. Found throughout the mountain, on rocks, living and dead trees and tree ferns and on shaded soil, often by streams, usually associated with epiphytes such as Campylopus and Fissidens spp., and Syrrhopodon gaudichaudii, 885-2180 m, June 1991. Forty one collections: Porley (4), Wigginton (7), Hodgetts (9), Kungu (4), Kathumba (2), O'Shea (13) and Longton (1). Tropical Africa, including Madagascar and Réunion.

Syrrhopodon gaudichaudii Mont. Rather less frequent than $S$. gardneri but with a similar distribution and habitat preference, although perhaps in slightly more protected areas, 1000$2225 \mathrm{~m}$, June 1991. Thirty one collections: Porley (4), Wigginton (10), Hodgetts (9), Kungu (2), Kathumba (1), O'Shea (5). Widespread in tropical and southern Africa.

Syrrhopodon subgenus Pseudocalymperes Lower Ruo Gorge, $15^{\circ} 57^{\prime}$ S 35 39'E, among and on stems of filmy fern on tree buttress, $1020 \mathrm{~m}$, 19 June 1991, Wigginton 1186c; The Crater, Muloza R., $16^{\circ} 1^{\prime} \mathrm{S} 35^{\circ} 32^{\prime} \mathrm{E}$, trunk of Newtonia tree in rain forest, $885 \mathrm{~m}, 30$ June 1991, Porley $327 c$. These collections require further study (L.T. Ellis, pers. comm.).

Syrrhopodon prolifer sensu lato Chisongoli, $16^{\circ} 1^{\prime} \mathrm{S} 35^{\circ} 43^{\prime} \mathrm{E}$, moist shaded rocks by river, in one case growing on tomentum on stem of Campylopus robillardei, 1220-1260 m, 16 June 1991, Wigginton 1004b, 1007b, 1010a, 1011a; Ruo R., immediately above waterfall, $15^{\circ} 55^{\prime} \mathrm{S}$ $35^{\circ} 38^{\prime} \mathrm{E}$, dry surface of exposed rocks, $1830 \mathrm{~m}$, 20 June 1991, Wigginton 1279c; Thuchila, Elephant's Head, $15^{\circ} 53^{\prime} \mathrm{S} 35^{\circ} 36^{\prime} \mathrm{E}$, soil at base of large boulder beside stream, $1700 \mathrm{~m}, 23$ June 1991, Porley 218c; Lichenya Plateau, Nessa Path, $15^{\circ} 59^{\prime} \mathrm{S} 35^{\circ} 33^{\prime} \mathrm{E}$, base of grassy tussock by stream, 1780 m, 28 June 1991, Hodgetts 2600 b. Elsewhere, in East Africa and the Indian Ocean islands.

*Syrrhopodon prolifer var. hispidocostatus Renauld \& Cardot in Renauld Valley immediately west of Minunu Hut, $15^{\circ} 55^{\prime} \mathrm{S}$ 35³8'E, Cyathea stem, 1980 m, 19 June 1991, O'Shea 7136b; Between Nandiwo and 
Nandalanda, $15^{\circ} 53^{\prime} \mathrm{S} 35^{\circ} 38^{\prime} \mathrm{E}$, on tree fern stem in forest patch, $2200 \mathrm{~m}$, 22 June 1991, Wigginton 1389a; Path from Lichenya Hut to Lichenya R., and near the river, $15^{\circ} 58^{\prime} \mathrm{S} 35^{\circ} 33^{\prime} \mathrm{E}$, stem of tree fern in humid forest, $1760 \mathrm{~m}, 27$ June 1991, Wigginton 1643a, 1643d, 1649a; tree fern stem at stream, edge of forest, 1720 m, 27 June 1991, Kungu 3302a; very wet seepages in deeplyshaded crevices by river, 1700 m, 28 June 1991, Wigginton 1683a; stem of tree fern in humid forest by river, $1700 \mathrm{~m}, 28$ June 1991, Wigginton 1701a, 1706a. First record for mainland Africa, although present in the East African islands.

*Syrrhopodon usambaricus Broth. ex Orbán Chisongoli, $16^{\circ} 1^{\prime} \mathrm{S} 35^{\circ} 43^{\prime} \mathrm{E}$, underside of overhang of large shaded granite boulder, $1625 \mathrm{~m}$, 17 June 1991, Porley 35a; vertical rock face, 1650 m, Hodgetts 2220b; Lower Ruo Gorge, $15^{\circ} 57^{\prime} \mathrm{S} 35^{\circ} 39^{\prime} \mathrm{E}$, buttress of forest tree, 1050 m, 19 June 1991, Hodgetts 2041d; Below Minunu Hut, Ruo valley, $15^{\circ} 56^{\prime} \mathrm{S} 35^{\circ} 38^{\prime} \mathrm{E}$, vertical rock face, $1650 \mathrm{~m}$, 17 June 1991, Hodgetts 2047c; Lichenya Plateau, Nessa Path, $15^{\circ} 59^{\prime}$ S 35 34'E, deeply shaded vertical rock in forest, $1800 \mathrm{~m}, 27$ June 1991, Porley 278a; Lichenya R., 1558'S $35^{\circ} 33^{\prime} \mathrm{E}$, very wet seepage in deeply-shaded crevices by river, $1700 \mathrm{~m}$, Wigginton 1682a; The Crater, Muloza R., $16^{\circ} 1^{\prime} \mathrm{S} 35^{\circ} 32^{\prime} \mathrm{E}$, twigs of tree in forest, 920m, 30 June 1991, Hodgetts 2669a. Known from Tanzania and Equatorial Guinea.

\section{CRYPHAEACEAE}

*Cryphaea protensa Bruch \& Schimp. ex Müll.Hal. Path to Chisongoli forest, $16^{\circ} 1^{\prime} \mathrm{S}$ $35^{\circ} 43^{\prime} \mathrm{E}$, scrub under rock overhang, $1550 \mathrm{~m}$, 17 June 1991, Hodgetts 2259a; Lichenya River, $15^{\circ} 58^{\prime}$ 'S $35^{\circ} 34^{\prime} \mathrm{E}$, branches of Hypericum shrub with Cryphaea robusta, 1700 m, 28 June 1991, O'Shea 7517b; both det. P. Rao. Cryphaea is a comparatively rare genus in the African tropics, and both species recorded here are known from only 3 other countries in Africa: Ethiopia, Kenya and Tanzania. It is interesting that both species were growing together at one locality, although in very small quantity. All three specimens consist of only a few stems, so it is possible that the genus has been overlooked, but a moist, sheltered, montane habitat seems also to be a common factor. [BJO]

*Cryphaea robusta Broth. \& Thér. Lichenya River, $15^{\circ} 58^{\prime} \mathrm{S} 35^{\circ} 34^{\prime} \mathrm{E}$, branches of Hypericum shrub with Cryphaea protensa, 1700 m, 28 June 1991, O'Shea 7517a; det P. Rao. See notes under C. protensa. [BJO]

\section{DICRANACEAE}

All specimens identified or confirmed by A.C. Crundwell unless otherwise stated.

\section{Aongstroemia filiformis (P.Beauv.) Wijk \&} Margad. Chinzama, $15^{\circ} 53^{\prime} S 35^{\circ} 39^{\prime} \mathrm{E}$, eroding gravelly edge of stream bank, $2120 \mathrm{~m}, 21$ June 1991, Porley 143a (det. RDP); loc. cit., 22 June 1991, 2135 m, Longton 8313a; Thuchila Plateau, Elephant's Head, $15^{\circ} 53^{\prime}$ S $35^{\circ} 35^{\prime}$ E, gravelly soil on sunny stream bank, 1690 m, 23 June 1991, Porley 211 a, Hodgetts $2315 b$; path by Lichenya River, $15^{\circ} 59^{\prime} \mathrm{S} 35^{\circ} 33^{\prime} \mathrm{E}$, boulders by river, 1720 m, 27 June 1991, Longton 8524a; loc. cit., exposed clay bank by path, $1700 \mathrm{~m}, 28$ June 1991, O'Shea 7526a. Recorded once previously in Malawi, on Mulanje, and distributed mainly in the southern part of the continent; also known from central and southern America.

Aongstroemia julacea (Hook.) Mitt. Thuchila to Chambe path, $15^{\circ} 55^{\prime} \mathrm{S} 35^{\circ} 34^{\prime} \mathrm{E}$, on compacted soil in crevice of rock by path, associated with Pleuridium sp., Archidium amplexicaule, Campylopus pilifer and Gongylanthus ericetorum, 2220 m, 26 June 1991, Porley $262 a$ (det. R.D. Porley). Recorded once previously for Malawi, from Mulanje, and with a similar, but slightly more limited, distribution to A. filiformis; however, its much smaller size may cause it to be collected less frequently. [BJO]

Dicranoloma billardierei (Brid.) Paris There were over 30 collections made of Dicranoloma, but so far only three have been identified, all as this taxon: Magombo 4277a, 4293a; Russell 6095a. One was collected on a tree near the Lichenya Hut at $1730 \mathrm{~m}$, but the other two were collected on rock at $2740 \mathrm{~m}$ and $2770 \mathrm{~m}$ on Sapitwa peak. The genus has been collected only once before in Malawi, on Mulanje, but clearly is quite common. The taxon occurs widely in the tropics and southern hemisphere. 
Leptotrichella minuta (Hampe) Ochyra (= Microdus minutus) Ruo Gorge, $15^{\circ} 56^{\prime} \mathrm{S}$ $35^{\circ} 38^{\prime} \mathrm{E}$, shaded soil bank along path in forest, 1980 m, 20 June 1991, Porley 120a; Thuchila Plateau, tributary of Thuchila River, $15^{\circ} 54^{\prime} \mathrm{S}$ $35^{\circ} 36^{\prime}$ E, earthy stream bank, $1890 \mathrm{~m}, 22$ June 1991, Hodgetts 2316a; Thuchila Plateau, Red Route shelter, $15^{\circ} 55^{\prime} \mathrm{S} 35^{\circ} 35^{\prime} \mathrm{E}$, moist river bank, 2200 m, 24 June 1991, Magombo 4265a; Chambe to Lichenya path, $15^{\circ} 58^{\prime} \mathrm{S} 35^{\circ} 33^{\prime} \mathrm{E}$, gravel soil near stream, 25 June 1991, Russell 6088b. This species has been found twice before on Mulanje, but not elsewhere in Malawi, and is most frequent in the south of the continent.

\section{DITRICHACEAE}

Ditrichum difficile (Duby) M.Fleisch. Found at various localities across the plateau, always on soil, from 1700-2245, but more frequently over 2000 m, Hodgetts 2489a; Kungu 3075a, 3174b, 3189a; Magombo 4184a, 4195a, 4251a, 4350a; O'Shea 7163b, 7194a, 7530b. RUMPHI: Nyika NP, $10^{\circ} \mathrm{S} 33^{\circ} \mathrm{E}$, at $2245 \mathrm{~m}, 29$ July 1993, Stevenson R42. All det. A.C. Crundwell. Not all Ditrichum specimens have yet been identified to species, and it likely that more collections of this taxon will appear, as it is widespread in the tropics and southern hemisphere, and has been found previously in Malawi at both Mulanje and Nyika, and also on Zomba Plateau.

\section{FABRONIACEAE}

*Fabronia abyssinica Müll.Hal. Chisongoli, near Muluzi River, $16^{\circ} 1^{\prime}$ S $35^{\circ} 42^{\prime}$ E, on vertical rock face, $760 \mathrm{~m}, 16$ June 1991, Wigginton $1143 a$, det. R.D. Porley. Widespread, East tropical, and southern Africa.

*Fabronia leikipiae Müll.Hal. Mulanje: road through Chitakali Estate, $16^{\circ} 1^{\prime} \mathrm{S} 35^{\circ} 31^{\prime} \mathrm{E}$, on roadside tree, $620 \mathrm{~m}, 1$ July 1991, Hodgetts $2700 c$, det. R.E. Magill. Scattered records from the Cape Verde Islands, Nigeria, and East- to southern Africa.

Fabronia pilifera Hornsch. Lauderdale Tea Estate, E. of Mulanje, $16^{\circ} 1^{\prime} \mathrm{S} 35^{\circ} 32^{\prime} \mathrm{E}$, epiphytic on tea-bush, 740-760 m, 30 June 1991, Porley 351a, Hodgetts 2697a, det. R.E. Magill. Mulanje Country Club, $16^{\circ} 1^{\prime} \mathrm{S} 35^{\circ} 31^{\prime} \mathrm{E}$, on trunk of Bauhinia, 640 m, 16 June 1991, Longton 8001 a. Widespread in tropical and southern Africa.

*Schwetschkea usambarica Broth. The Crater, $16^{\circ} 1^{\prime} \mathrm{S} 35^{\circ} 32$ 'E, epiphytic on Newtonia tree, 840 m, 30 June 1991, Hodgetts 2696b, det. R.E. Magill. Otherwise recorded only from D.R. Congo, Kenya, Tanzania and Zambia.

\section{FISSIDENTACEAE}

All collections identified or confirmed by M.A. Bruggeman-Nannenga. The distribution of this family in Africa is being reviewed in parallel with a taxonomic revision, so will be published as part of the wider study.

Fissidens androgynus Bruch ex C.Krauss ( $F$. bryoides var. bryoides Hedwig sensu Magill). Sombani Basin, $15^{\circ} 53^{\prime} \mathrm{S} 35^{\circ} 42^{\prime} \mathrm{E}$, rock in open forest, $2080 \mathrm{~m}, 21$ June 1991, O'Shea 7233b; Widdringtonia stand, Chinzama to Sombani path, $15^{\circ} 53^{\prime} \mathrm{S} 35^{\circ} 39^{\prime} \mathrm{E}$, on rotting wood, $2180 \mathrm{~m}, 22$ June 1991, Longton 8285a; Forest NE of Chambe Hut, $15^{\circ} 53^{\prime} \mathrm{S} 35^{\circ} 32^{\prime} \mathrm{E}$, leaf litter in shaded hollow by boulder, 1900 m, 25 June 1991, Longton 8429x; Chapaluka Path, $15^{\circ} 55^{\prime}$ 'S 3532'E, silty soil by stream with Fissidens curvatus and $F$. asplenioides, 1420 m, 7 August 1993, Stevenson $R 142 b$. On various substrates, between 1420 and $2180 \mathrm{~m}$.

This species was previously reduced to $F$. bryoides Hedw. (Magill, 1981). It was also cited as F. bryoides sensu lato (Bruggeman-Nannenga, 1993). In the Americas as well as in Europe, Africa and Asia, intermediates are found that at first sight seem to be distinct species, e.g. $F$. bryoides, F. viridulus Swartz, and F. schmidii Müll.Hal. This situation has been expressed in different ways. American authors, e.g. Crum (1973), Crum and Anderson (1981), consider F. bryoides to be a broad species or species complex with many expressions. These same expressions (e.g. viridulus) are treated in Europe as species or varieties (e.g. Smith, 1978), and in Asia as forms, varieties or subspecies (e.g. Chopra \& Kumar, 1981, and Eddy, 1988). The reduction of $F$. androgynus to F. bryoides in Magill (1981) 
can be seen in the scope of this very broad concept of $F$. bryoides. In my opinion, however, using the name $F$. bryoides for the African material does not do justice to the situation. The antheridia in the African material are, without exception, terminal, whereas $F$. bryoides var. bryoides is gonioautoicous, and the African material is much more robust than $F$. viridulus, which also has terminal antheridia. I therefore prefer to recognize these plants as $F$. androgynus. This species might be confused with another taxon belonging to this complex that also occurs in Africa, $F$. schmidii, $\omega \eta \imath \eta \delta 1 \phi \phi \varepsilon \rho \sigma \imath v \tau \eta \varepsilon \sigma \mu \alpha \lambda \lambda(7.5(\mu)$, $\sigma \tau \rho \circ \nu \gamma \lambda \psi \chi \chi 0 \nu \varpi \varepsilon \xi \chi \varepsilon \lambda \lambda \sigma, \alpha \nu \delta \tau \eta \varepsilon \delta \varepsilon \lambda \iota \chi \alpha \tau \varepsilon$

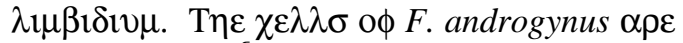
$\lambda \alpha \rho \gamma \varepsilon \rho(6-13.5$ ( $\mu) \alpha v \delta \phi \lambda \alpha \tau, \alpha v \delta \tau \eta \varepsilon \pi \lambda \alpha v \tau \sigma$, $\alpha \sigma \omega \varepsilon \lambda \lambda \alpha \sigma \tau \eta \varepsilon \lambda \iota \mu \beta \imath \delta \imath \mu, \alpha \rho \varepsilon \mu о \rho \varepsilon \rho о \beta v \sigma \tau$.

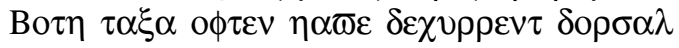
$\lambda \alpha \mu \mathrm{iv} \alpha \varepsilon$. [MABN].

Fissidens asplenioides Hedw. Fifty-eight collections from Mt. Mulanje: Pócs \& Magombo (3) (EGR, U); Wigginton (5); Hodgetts (11); Kungu (9); Magombo (3); Kathumba (4); Russell (3); O'Shea (15); Longton (4); Rammeloo (1) (all E); Stevenson (6) collected on both Mulanje and in RUMPHI: Nyika NP. Also found in ZOMBA, Zomba Plateau: Townsend (2) (K) and Long (1). Most abundant on the plateau, almost always by shaded streams or occasionally in moist areas of grassland, growing on rocks, peaty soil or soil banks, alluvium, tree roots or rotten wood, 800$2280 \mathrm{~m}$.

This characteristic species can be recognized in the dry state by its inrolled leaf tips. Microscopically it is characterized by obtuse leaf tips with short costae; the smaller of the two vaginant laminae has a rounded apex and ends at or near the costa. [MABN].

* $\boldsymbol{F}$. bogosicus Müll.Hal. in Venturi Eastern Chambe Peak, $15^{\circ} 53^{\prime} \mathrm{S} 35^{\circ} 32^{\prime} \mathrm{E}$, xerophyta bush on open granitic rocks, under rock overhang, 2000-2200 m, 13 April 1991, Pócs \& Magombo 9176/O (U, EGR); at south foot of eastern Chambe Peak, $15^{\circ} 53$ 'S $35^{\circ} 32^{\prime} \mathrm{E}$, on cliff in montane evergreen forest fragment, 1920-1970 m, 15 April 1991, Pócs \& Magombo 9182/E (EGR, U); Chisongoli, $16^{\circ} 0^{\prime} \mathrm{S} 35^{\circ} 43^{\prime} \mathrm{E}$, shaded, moist, vertical face of boulder in cleared area, amongst tall grass and herbs, $1560 \mathrm{~m}, 17$ June 1991, Wigginton 1103a; Slopes of Chisongoli, $16^{\circ} 0^{\prime} \mathrm{S} 35^{\circ} 43^{\prime} \mathrm{E}$, on rock surface in cleared area, 1500 m, 7 June 1991, Wigginton 1111a, Hodgetts $2360 a$; by track from Chinzama Hut towards Sombani Hut, $15^{\circ} 53^{\prime} \mathrm{S} 35^{\circ} 39^{\prime} \mathrm{E}$, isolated Widdringtonia stand on boulder in moist gully, 1700 m, 22 June 1991, Longton 8287x. On rocks in open places and forests, $1500-2200 \mathrm{~m}$.

The following specimens are the "rotereaui form" of F. bogosicus (see below). Mulanje Mt: NW part at S foot of eastern Chambe Peak, $15^{\circ} 53^{\prime} \mathrm{S} 35^{\circ} 32^{\prime} \mathrm{E}$, montane evergreen forest fragment, rupicolous, 1920-1970 m, 15 April 1991, Pócs \& Magombo 9182/C (EGR, U); Upper Ruo valley, $15^{\circ} 55^{\prime} \mathrm{S} 35^{\circ} 38^{\prime} \mathrm{E}$, rock by path in forest, 1960 m, 20 June 1991, Wigginton 1257a; Mt. Ruo Basin, below Chinzama Hut, $15^{\circ} 53^{\prime} \mathrm{S} 35^{\circ} 39^{\prime} \mathrm{E}$, on damp rocks in deep shade in stream gully, $2130 \mathrm{~m}, 21$ June 1991, Hodgetts 2154a; Sapitwa, 1556'S 35³5'E, soil in cave, 2890 m, 25 June 1991, Magombo 4297a; valley immediately west of Minunu hut, $15^{\circ} 55^{\prime} \mathrm{S}$ $35^{\circ} 38^{\prime} \mathrm{E}$, cleft in tree root by stream, $1980 \mathrm{~m}, 19$ June 1991, O'Shea 7131e. ZOMBA: S escarpment of Zomba Plateau, S slope of Kuchawe summit, $15^{\circ} \mathrm{S} 35^{\circ} \mathrm{E}$, mesic montane forest in gullies, terricolous, 1380-1500m, 7 April 1991, Pócs 9171/BB, BC, BD (all EGR, U), associated with $F$. enervis. On rocks or earth in humid, shady places in forests, in a cave, near a stream, 1380-2890 m.

$F$. rotereaui was reduced to $F$. bogosicus (Bruggeman-Nannenga, 1997), but in Malawi the two taxa are distinct. F. bogosicus is characterised by unequal vaginant laminae and limbidia that are restricted to the very base of the vaginant laminae. Fissidens rotereaui has (nearly) equal, completely limbate vaginant laminae, and seems to prefer more humid habitats. On the basis of the Malawi material, it seems that the two are good species, but material from other areas is needed for study. [MABN].

Fissidens crispulus Brid. Mulozi R., east of Songwe, $16^{\circ} 1^{\prime} \mathrm{S} 35^{\circ} 42^{\prime} \mathrm{E}$, shaded rock by river and open ground along track, $730 \mathrm{~m}, 18$ June 1991, Magombo 4072a, $4101 a$.

*Fissidens curvatus Hornsch. var. curvatus 
Thuchila Plateau, S side of Elephant's Head, $15^{\circ} 53^{\prime} \mathrm{S} 35^{\circ} 36^{\prime} \mathrm{E}$, sunny rock by firebreak, 1720 m, 23 June 1991, Hodgetts 2355a; Chapaluka path to Chambe Basin, $15^{\circ} 55^{\prime} \mathrm{S} 35^{\circ} 32^{\prime} \mathrm{E}$, silty soil by side of stream with $F$. androgynus and $F$. asplenioides, 1420 m, 7 August 1993, Stevenson R142a; by track from Chinzama Hut towards Sombani Hut, $15^{\circ} 53^{\prime} \mathrm{S} 35^{\circ} 39^{\prime} \mathrm{E}$, on boulder in moist gully, in isolated Widdringtonia stand, mixed with other Fissidens species, 2180 m, 22 June 1991, Longton 8287w. BLANTYRE: Devlin road, Nyambadwe, $15^{\circ} 46^{\prime} \mathrm{S} 35^{\circ} 1^{\prime} \mathrm{E}$, on earth bank, 1045 m, 8 May 1980, Townsend 80/ 48 and $80 / 49 a(\mathrm{~K})$. THYOLO: at SE corner of Cholo, ca. $3.5 \mathrm{~km} \mathrm{~W}$ of Satema, $16^{\circ} \mathrm{S} 35^{\prime} \mathrm{E}$, on earth bank, 1135 m, 12 May 1980, Townsend 80/ $94(\mathrm{~K})$. Found on soil and rock between 1045$1720 \mathrm{~m}$.

Fissidens ellipticus Besch. Chisongoli, $16^{\circ} 0^{\prime} \mathrm{S}$ $35^{\circ} 43^{\prime} \mathrm{E}$, on trunk of tree in open by path, 1630 m, 17 June 1991, Porley 39a; loc. cit., trunk of mature tree in forest, scattered stems in bryophyte mat, 1680 m, 17 June 1991, Wigginton 1076d; Upper Ruo Gorge, $15^{\circ} 56^{\prime}$ 'S $35^{\circ} 38^{\prime} \mathrm{E}$, tree trunk in deep shade, with filmy ferns, $1850 \mathrm{~m}, 26$ June 1991, Hodgetts 2074a.

This is an arboricolous, nearly elimbate, unipapillose species with wide, often obtuse leaves and costae that end 2-3 cells below the leaf apex. [MABN].

*Fissidens enervis Sim ZOMBA. Zomba Plateau, S slope of Kuchawe summit, $15^{\circ} \mathrm{S} 35^{\prime} \mathrm{E}$, mesic montane forest in gully, terrestrial, 1380$1500 \mathrm{~m}$, Pócs 9171/ BB, BC and BD (all EGR, $\mathrm{U})$, mixed with $F$. bogosicus ('rotereaui') and $F$. intramarginatus..

This is the only ecostate species that has been found in Malawi. [MABN].

*Fissidens gardneri Mitt. R. Mulozi, above Hutson's house, $16^{\circ} 1^{\prime} \mathrm{S} 35^{\circ} 42^{\prime} \mathrm{E}$, trunk of Macaranga tree in well-illuminated site by river, 760 m, 18 June 1991, Wigginton 1139a. MANGOCHI: Cape Maclear: Nkhunguni trail, Nkhunguni Hill, 135'ㅇ 3449'E, fibrous stem of Aloe, 785 m, 10 August 1993, Stevenson R216a.

A characteristic, small, multipapillose, arboricolous species in which the smaller of the vaginant laminae ends at or near the costa. It has obtuse leaf tips, short costae which are in the upper part often obscured by small, chlorophyllose cells, and short limbidia that are restricted to the vaginant laminae of perichaetial leaves. [MABN].

Fissidens intramarginatus Hampe Mulanje Mt.: Pócs \& Magombo 9182/C and 9182/E (EGR, U); Porley 319a; Wigginton $1158 a$ and 1524a; Hodgetts 2011a, 2662g; Kungu 3001x, 3050a, 3237x; Magombo 4035a; Kathumba 5109a; O'Shea 7002d, 7131f, 7561x; Longton 8287y. RUMPHI: Nyika NP, $10^{\circ} \mathrm{S} 33^{\circ} \mathrm{E}$, July 1993 , Stevenson R048b. ZOMBA: Pócs 9171/AM, BD and $Z$ (EGR, U); Long 12529. From 730-2245 $\mathrm{m}$ on shady soil banks, boulders, and tree bases and roots, usually near water, associated with various epiphytes, together with $F$. asplenioides, $F$. plumosus, F. sciophyllus, F. submarginatus and $F$. bogosicus.

This variable multipapillose species might be confused with the unipapillose $F$. submarginatus that also has a limbidium the whole length of the vaginant laminae. Typically, the papillae are high in $F$. submarginatus, but plants with lower ones are occasionally found. The shape and number of papillae in $F$. intramarginatus are variable, and specimens with unipapillose cells mixed with a few bipapillose cells occur. [MABN].

*F . jonesii Bizot ex Pócs Lichenya Plateau, Nessa path, $15^{\circ} 59^{\prime} \mathrm{S} 35^{\circ} 34^{\prime} \mathrm{E}$, Newtonia forest, foliicolous on small tree, $1800 \mathrm{~m}, 27$ June 1991, Porley $281 b$; Lujeri forest, $15^{\circ} 58^{\prime}$ S $35^{\circ} 37^{\prime} \mathrm{E}$, on bark of Psychotria tree on river bank, with $F$. sigmocarpoides, 1120 m, 17 June 1991, Kathumba 5906d. On tree bark, rarely on leaves, between 1120-1800 m altitude.

This unipapillose species might be confused with $F$. ramulosus, but setae of the latter are longer (more than $2 \mathrm{~mm}$ ), whereas setae of $F$. jonesii are less than $1.5 \mathrm{~mm}$. Fissidens sigmocarpoides, also a corticolous species, differs by its shorter costae ending 9-20 cells below the leaf apex. [MABN].

F. megalotis Schimp. ex (Müll.Hal.) subsp. 
helictocaulos (Müll.Hal.) Brugg.-Nann. BLANTYRE. About the 'saddle' of the hill Nyambadwe, $2 \mathrm{~km}$ N of Blantyre, $15^{\circ} 47^{\prime} \mathrm{S}$ $35^{\circ} 0$ 'E, on rock with a thin covering of earth, 1200 m, 8 May 1980, Townsend 80/24 (K); NE slope of Soche, c. $4 \mathrm{~km} \mathrm{~S}$ of Blantyre, $15^{\circ} 51^{\prime} \mathrm{S}$ $35^{\circ} 0$ 'E, on earth and stone, $1300 \mathrm{~m}, 8$ May 1980 , Townsend 80/39 (K); Devlin road, Nyambadwe, $15^{\circ} 47^{\prime} \mathrm{S} 35^{\circ} 0$ ' $\mathrm{E}$, on earth bank, $1045 \mathrm{~m}, 8$ May 1980, Townsend 80/49b (K), mixed with $F$. curvatus. Only collected near Blantyre, on earth between 1045 and $1200 \mathrm{~m}$.

This species has completely limbate leaves, unequal vaginant laminae and small, 6-

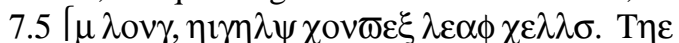

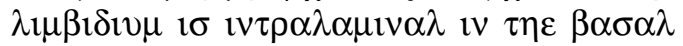

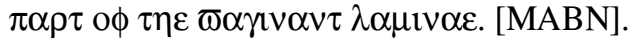

Fissidens ovatus Brid. The most frequently collected species on Mulanje Mt. (63 collections), and found throughout the collecting area. Newman \& Whitmore (1) (MO); Pócs \& Magombo (5) (EGR, U); Porley (5); Wigginton (6); Hodgetts (10); Kungu (11); Magombo (1); Kathumba (3); Russell (3); O'Shea (10); Longton (5); Stevenson (3). ZOMBA: Zomba Mt.: Pócs (2) (U). RUMPHI: Nyika Plateau: Stevenson (1). THYOLO: Townsend (1) (K). From 730-2280 $\mathrm{m}$, always by or in rivers and streams, on silt, soil, humus, rock and tree-ferns. Over 30 associated bryophyte species have been recorded.

*Fissidens pallidinervis Mitt. (= F. minutus Thwaites \& Mitt. var. minutus. cf. Pursell in Crosby, 1999). Chisongoli, $16^{\circ} 1^{\prime} \mathrm{S} 35^{\circ} 42^{\prime} \mathrm{E}$, moist, shaded, vertical rock face by river, 1220 m, 16 June 1991, Wigginton 1006b; gorge of Muluzi R., $16^{\circ} 1^{\prime}$ 'S $35^{\circ} 42^{\prime} \mathrm{E}$, side of boulder near lip of ravine, $740 \mathrm{~m}, 18$ June 1999, Hodgetts 2029a, 2030a; The Crater, Muloza river, $16^{\circ} 1^{\prime} \mathrm{S}$ $35^{\circ} 32^{\prime} \mathrm{E}$, rocks near waterfall, $940 \mathrm{~m}$, 30 June 1991, Hodgetts 2681a; Madzeka Path, 1558'S $35^{\circ} 39^{\prime} \mathrm{E}$, on rotting tree trunk in riverine forest, 800 m, 16 June 1991, O'Shea 7002x. Found in humid places on rock and wood, 740-1220 m.

This species has multipapillose cells, costae ending 8-14 cells below an obtuse apex, and limbidia restricted to the vaginant laminae of perichaetial leaves. [MABN].
Fissidens plumosus Hornsch. 48 collections from throughout the collecting area, always by streams and almost always on rock, but also on soil, humus and tree roots, 885-2310 m. Pócs \& Magombo (1) (U, EGR); Porley (5); Wigginton (5); Hodgetts (6); Kungu (16); Magombo (1); Kathumba (3); Russell (2); O’Shea (3); Longton (5); Rammeloo (1).

*Fissidens porrectus Mitt. Ruo valley below Minunu Hut, $15^{\circ} 57^{\prime} \mathrm{S} 35^{\circ} 39^{\prime} \mathrm{E}$, soil bank by path, 1260 m, 19 June 1991, Wigginton 1189a; vertical rock face by path, Hodgetts 2047a; Upper Ruo Gorge, $15^{\circ} 56^{\prime} \mathrm{S} 35^{\circ} 38^{\prime} \mathrm{E}$, wet peaty soil in dark cleft in rock face, $1900 \mathrm{~m}, 20$ June 1991, Wigginton 1249b. ZOMBA, S escarpment of Zomba plateau, gullies of the $\mathrm{S}$ slope of Kuchawe summit, $15^{\circ} \mathrm{S} 35^{\prime} \mathrm{E}$, mesic montane forest, on roadcut, terricolous, 1380-1500 m, 7 April 1991, Pócs 9171/BT (EGR, U). On soil and rock, 1260$1900 \mathrm{~m}$.

\section{*F. pseudoeenii Bizot \& Dury ex Pócs} Chinzama to Sombani path, $1^{\circ} 5^{\prime}$ 'S $35^{\circ} 39^{\prime} \mathrm{E}$, Widdringtonia stand, on rotting wood, $2180 \mathrm{~m}$, 22 June 1991, Longton 8285y.

Pursell and Bruggeman-Nannenga (1996) reduced this species to $F$. serratus var. leptochaete. F. serratus has unipapillose cells and var. leptochaete differs from var. serratus in the presence of an intralaminal limbidium on all or most leaves. The inner laminal cells of Longton $8285 y$, however, are smooth and slightly convex and what at first sight looks strikingly like large papillae are in fact guttulae, although marginal cells are often unipapillate. Re-examination of the type-specimen of $F$. pseudoeenii made clear that the laminal cells are smooth, though eguttulate. The smooth cells separate it from $F$. serratus. It is close to $F$. flabellulus Thwaites \& Mitt. from Asia which, however is elimbate.

$F$. pseudoeenii is recognized by its small, 1-2 mm tall plants, large, 9-15 $\int \mu \lambda$ ov $\gamma, \sigma \mu$ oo $\eta$

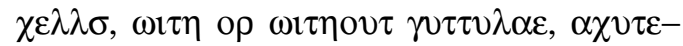
$\alpha \chi v \mu 1 v \alpha \tau \varepsilon \lambda \varepsilon \alpha \phi \tau \imath \pi \sigma, \varepsilon \xi \chi v \rho \rho \varepsilon \nu \tau \chi 0 \sigma \tau \alpha \varepsilon \alpha \nu \delta$ $\sigma \eta о \rho \tau \operatorname{lv} \tau \rho \alpha \lambda \alpha \mu \imath v \alpha \lambda \lambda \imath \mu \beta \imath \delta 1 \alpha$ ov $\tau \eta \varepsilon$

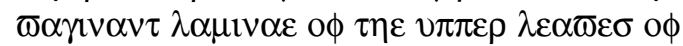
$\phi \varepsilon \mu \alpha \lambda \varepsilon \pi \lambda \alpha \nu \tau \sigma$. [MABN].

*Fissidens ramulosus Mitt. NKHATA BAY: 
Vizava Rubber Estate, S of Nkhata Bay, on road to Chinteche, $11^{\circ} 42^{\prime} \mathrm{S} 34^{\circ} 20^{\prime} \mathrm{E}$, bare soil on steep bank, with F. sciophyllus, 580 m, 1 August 1993, Stevenson R081a. ZOMBA, S escarpment of Zomba Plateau, on the S slope of Kuchawe Peak, $15^{\circ} \mathrm{S} 35^{\prime} \mathrm{E}$, on rock in rocky miombo woodland, 1400-1520 m, 7 April 1991, Pócs 9170n (EGR, $\mathrm{U})$. On soil and rock from $580-1520 \mathrm{~m}$.

Fissidens reflexus Hampe Chapaluka path, $15^{\circ} 56^{\prime} \mathrm{S} 35^{\circ} 30^{\prime} \mathrm{E}$, soil on vertical rock face, 890 m, 30 June 1991, Wigginton 1738b; W foot of Mulanje Mt., Likhubula Valley, fragments of dry evergreen forest, $770 \mathrm{~m}, 18$ April 1991, Pócs 9190/A (EGR, U); Lichenya to Likhubula path, $15^{\circ} 56^{\prime} \mathrm{S} 35^{\circ} 31^{\prime} \mathrm{E}$, ground in dry woodland, 1230 m, 29 June 1991, Longton 8599a. On soil, between $770-1230 \mathrm{~m}$.

This species is characterised by high conical to unipapillose cells, wide vaginant laminae and the presence of short limbidia on the vaginant laminae of many leaves. A similar African species, not known from Malawi, is Fissidens pocsii Bizot \& Dury ex Pócs. It differs in its very short setae (less than $1.4 \mathrm{~mm}$ long) and its arboricolous habitat. [MABN].

*Fissidens rufescens Hornsch. NE of Chambe Hut, $15^{\circ} 53^{\prime} \mathrm{S} 35^{\circ} 32^{\prime} \mathrm{E}$, soil bank by stream in indigenous woodland, 1895 m, 25 June 1991, Kungu $3237 y$.

*F. schmidii Müll.Hal. Chambe Basin; $15^{\circ} 54^{\prime}$ S $35^{\circ} 32^{\prime} \mathrm{E}$, on shaded rock in Cupressus-Pinus forest, 1880 m, 25 June 1991, Wigginton 1528a; near Forest Dept. Staff Quarters, Sombani Basin, $15^{\circ} 53^{\prime} \mathrm{S} 35^{\circ} 42^{\prime} \mathrm{E}$, tree bark in open woodland, 2060 m, 21 June 1991, O'Shea 7228f; forest NE of Chambe Hut, $15^{\circ} 53$ 'S $35^{\circ} 32^{\prime} \mathrm{E}$, leaf litter in shaded hollow by boulder, $1900 \mathrm{~m}, 25$ June 1991 , Longton 8429a. THYOLO: Cholo Mountain Forest Reserve, ca. $3.5 \mathrm{~km} \mathrm{~W}$. of Satema, $16^{\circ} \mathrm{S}$ $35^{\prime} \mathrm{E}$, on earthy bank, $1135 \mathrm{~m}, 12$ May 1980, Townsend 80/93 (K). ZOMBA: Zomba Plateau, below Malumbe Peak, $15^{\circ} \mathrm{S}$ 35'E, on wet rock in broad-leaved forest, $1780 \mathrm{~m}, 4$ April 1985, Long 12612 (E); S escarpment of Zomba Plateau, S slope of Kuchawe summit, $15^{\circ} \mathrm{S} 35^{\prime} \mathrm{E}$, on stone in mesic montane forest, 1380-1500 m, 7 April 1991, Pócs 9171/BR (EGR, U). Mainly on stone, also on bark and soil, between 1135 and $2060 \mathrm{~m}$. This species is characterized by convex cells, about 7.5 ìm long, which are often arranged in rows, completely limbate leaves, and the (almost) equal vaginant laminae. See also the remarks under $F$. androgynus. [MABN].

*Fissidens sciophyllus Mitt. var. sciophyllus. Generally distributed on Mulanje Mt., 35 collections. On humus, soil, and a termite nest, mainly on rock and wood, sometimes by streams, 460-2140 m, associated with 24 other bryophyte taxa, mainly epiphytes, including 7 other species of Fissidens. Pócs \& Magombo (1); Porley (1); Wigginton (8); Hodgetts (14); Kungu (1); Magombo (1); Kathumba (1); O'Shea (4); Stevenson (4). Also recorded in the following districts: Zomba, Nkhata Bay, Mangochi (Cape Maclear), Salima and Blantyre.

*Fissidens sciophyllus var. ulna (Müll.Hal.) Brugg.-Nann. Madzeka Path, 1558'S 3540'E, upper limit of planted pine, $1050 \mathrm{~m}, 16$ June 1991, Kungu 3017a.

*Fissidens serratus Müll.Hal. var. serratus. Chisongoli, $16^{\circ} 0^{\prime} \mathrm{S} 35^{\circ} 43^{\prime} \mathrm{E}$, decaying bark of fallen tree in deep shade, 1625 m, 17 June 1991, Wigginton 1052a; E of Minunu Hut, Ruo valley, 15'55'S 35³8'E, tree bark, 1980 m, 19 June 1991, O'Shea 7170d.

A small, variable, unipapillose, elimbate or weakly limbate species. [MABN].

*Fissidens sigmocarpoides P.de la Varde Lujeri forest, 15 $58^{\circ}$ 'S $35^{\circ} 37^{\prime} \mathrm{E}$, on bark of Psychotria tree on river bank, with Fissidens jonesii, 1120 m, 17 June 1991, Kathumba 5906b.

A corticolous, unipapillose species, with costa ending 6-20 cells below apex. [MABN].

*Fissidens submarginatus Bruch ex Krauss. NW part of Mulanje Mountains, $S$ foot of eastern Chambe Peak, $15^{\circ} 53^{\prime} \mathrm{S} 35^{\circ} 32^{\prime} \mathrm{E}$, montane evergreen forest fragment, on cliff mixed with F. bogosicus and F. intramarginatus, 1920-1970 m, 15 April 1991, Pócs \& Magombo 9182/E (EGR, U); Chisongoli, $16^{\circ} 0$ 'S 35 43'E, on shaded moist soil in forest, $1630 \mathrm{~m}, 17$ June 1991 , Magombo 4035x; Chisongoli, $16^{\circ} 0^{\prime} \mathrm{S} 35^{\circ} 43^{\prime} \mathrm{E}$, 
small rock on forest floor, 1635 m, 17 June 1991, Wigginton 1066b; Mulozi R., E of Songwe, $16^{\circ} 1^{\prime} \mathrm{S} 35^{\circ} 42^{\prime} \mathrm{E}$, damp shaded soil by river, 740 m, 18 June 1991, Porley 71d; Upper Thuchila valley, $15^{\circ} 55^{\prime} \mathrm{S} 35^{\circ} 33^{\prime} \mathrm{E}$, moist soil by stream in broadleaf evergreen wood, 1900 m, 26 June 1991, Longton 8464a; Lauderdale Tea Estate, $16^{\circ} 1$ 'S $35^{\circ} 32^{\prime} \mathrm{E}$, soil bank by path in tea plantation, 850 m, 30 June 1991, Longton 8606a. ZOMBA, S escarpment of Zomba Plateau, S slope of Kuchawe summit, $15^{\circ} \mathrm{S} 35^{\prime} \mathrm{E}$, mesic montane forest in gully, terricolous, with $F$. intramarginatus, 1380-1500 m, 7 April 1991, Pócs 9171/AM (EGR, U). THYOLO, Nchima Estate by Nsikidzi River, $5 \mathrm{~km}$ SE of Thyolo, $16^{\circ} 4^{\prime} \mathrm{S} 35^{\circ} 8^{\prime} \mathrm{E}$, on earth at tree base, $717 \mathrm{~m}, 12$ May 1980, Townsend 80/58(K). In Malawi found between 740-1970 m, on soil or rock in forests. See also remarks under $F$. intramarginatus. [MABN].

\section{LEUCOBRYACEAE}

Octoblepharum albidum Hedw. Above Big Ruo River valley, $15^{\circ} 58^{\prime} \mathrm{S} 35^{\circ} 40^{\prime} \mathrm{E}$, burnt rotten $\log$, 1070 m, 16 June 1991, O'Shea 7032b; Lower Ruo Gorge, $15^{\circ} 57^{\prime} \mathrm{S} 35^{\circ} 39^{\prime} \mathrm{E}$, shaded tree buttress in rain forest, $1000 \mathrm{~m}, 19$ June 1991, Wigginton $1170 d ; 1.5 \mathrm{~km}$ from Likhubula along Lichenya Path, $15^{\circ} 56^{\prime} \mathrm{S} 35^{\circ} 31^{\prime} \mathrm{E}$, tree in Brachystegia woodland, 1000 m, 29 June 1991, Hodgetts 2636a; The Crater: Mulozi River, $16^{\circ} 1^{\prime} \mathrm{S} 35^{\circ} 32^{\prime} \mathrm{E}$, tree bark and rocks near river, 840-885 m, 30 June 1991, Porley 320a, Hodgetts 2644a, Hodgetts 2693a, O'Shea 7541a, Longton 8621 a All specimens identified or confirmed by L.T. Ellis. A common pantropical species, mainly at lower altitudes.

\section{MNIACEAE}

Plagiomnium rhynchophorum (Hook.) T.J.Kop. Frequent throughout the forested areas, all but 4 of the 30 collections made between 2070$2180 \mathrm{~m}$, on rocks, soil, leaf litter, tree roots and tree branches, often creeping through other bryophytes; Porley (1), Wigginton (1), Hodgetts (2),Kungu (3), Magombo (2), Kathumba (1), Russell (4), O'Shea (14), Longton (4). Most specimens det. T. Koponen, others by R.E.
Longton. Widely distributed in tropical Africa. ORTHOTRICHACEAE

All specimens identified or confirmed by M.J. Wigginton unless otherwise stated.

\section{Macrocoma abyssinica (Müll.Hal.) Vitt Near} Lichenya River, $15^{\circ} 59^{\prime} \mathrm{S} 35^{\circ} 33^{\prime} \mathrm{E}$, epiphytic on thin twigs arising at the nodes of bamboo, with Daltonia sp., Metzgeria sp., small Lejeuneaceae and foliose lichens, $1720 \mathrm{~m}$, Longton 8519b. Second record from Malawi. Cameroon, and from Ethiopia south to South Africa.

Macrocoma tenuis var.tenuis (Hook. \& Grev.) Vitt Mainly on well-illuminated twigs and branches of trees and shrubs, including nodes of bamboo, but also on trunks, including those of Vellozia and Eucalyptus, often abundantly fertile. Recorded associates include Brachymenium sp., Cheilolejeunea krakakammae, Daltonia sp., Drepanolejeunea cultrella, Frullania arecae, Leucolejeunea xanthocarpa, Lejeunea sp., Metzgeria spp., Schiffneriolejeunea pappeana. Chinzama, 1553'S 35³9'E, 2225 m, 21 June 1991; Chagaru, 1553'S 3540’E, 2320 m, 21 June 1991, Wigginton 1348c. Chinzama to Sombani path, $15^{\circ} 54^{\prime}$ 'S 35 40 'E; $2190 \mathrm{~m}$, 20 June 1991, O'Shea 7206a, 7207a. Lichenya, 1558'S 35³3'E, 1720 m, 27 June 1991, Wigginton 1667b; Kungu 3322a, 3331a; Longton 8516a, $8519 b$. Chinzama to Thuchila path, $15^{\circ} 53^{\prime} \mathrm{S}$ 35³6'E, $1800 \mathrm{~m}$, 23 June 1991, O'Shea 7374a; $15^{\circ} 53^{\prime} \mathrm{S} 35^{\circ} 38^{\prime} \mathrm{E}, 2200 \mathrm{~m}, 22$ June 1991, O'Shea $7341 a$. Nessa path, $15^{\circ} 58^{\prime} \mathrm{S} 35^{\circ} 33^{\prime} \mathrm{E}, 1780-1860$ m, 28 June 1991, Porley 308a, Hodgetts 2579e. Ruo Gorge, $15^{\circ} 55^{\prime} \mathrm{S} 35^{\circ} 38^{\prime} \mathrm{E}, 1860-1930 \mathrm{~m}, 20$ June 1991, Hodgetts 2062c, 2116e. Thuchila, 155'ㅇ 3536'E, 1700 m, 23 June 1991, Magombo 4245a. Eastern and southern Africa, St. Helena.

\section{POTTIACEAE}

All specimens identified or confirmed by $\mathrm{P}$. Sollman unless otherwise stated.

*Anoectangium aestivum (Hedw.) Mitt. Chapaluka Path from Likhubula to Chambe, [6836], soil on vertical rock face by path, $890 \mathrm{~m}$, 30 June 1991, Wigginton 1736a. A scattered distribution in tropical Africa. 
Barbula indica var. indica (Hook.) Spreng. Gorge of Muluzi River, below Hutson's House, $16^{\circ} 2^{\prime} \mathrm{S} 35^{\circ} 43^{\prime} \mathrm{E}$, on thin soil over rock in rockery in garden, 740 m, 18 June 1991, Hodgetts $2279 b$ (det. P. Sollman); Lujeri Tea Estate, No. 3 shed, $15^{\circ} 59^{\prime} \mathrm{S} 35^{\circ} 39^{\prime} \mathrm{E}$, sides of granitic and concrete culvert, 780 m, 18 June 1991, Longton $8102 a$ (det. A.C. Crundwell), 8108b, 8111b, 8112a. Associates: Bryum argenteum, B. ?caespiticium, Hyophila involuta. A widespread pantropical species.

*Bellibarbula recurva (Griff.) R.H.Zander Muluzi River, $16^{\circ} 1^{\prime} \mathrm{S} 35^{\circ} 43^{\prime} \mathrm{E}$, rocks within river channel, submerged when water level high, 1220 m, 16 June 1991, Porley 11a; rock crevice in flat river rocks and grassy tussock in river, $1260 \mathrm{~m}$, 16 June 1991, Hodgetts 2019b, 2021h; above waterfall in Thuchila River, $15^{\circ} 54^{\prime} \mathrm{S} 35^{\circ} 36^{\prime} \mathrm{E}$, vertical exposed rock face, $1680 \mathrm{~m}, 23$ June 1991 , Hodgetts 2361a; path from Thuchila Hut to Lukhulezi, $15^{\circ} 5^{\prime}$ 'S $35^{\circ} 37^{\prime}$ E, exposed north-west facing granitic rock, $1800 \mathrm{~m}, 23$ June 1991, Longton 8349a; The Crater, $16^{\circ} 1^{\prime} \mathrm{S} 35^{\circ} 32^{\prime} \mathrm{E}$, periodically flushed inclined faces of granitic rock on stream bed, 950 m, 30 June 1991, Porley 350a. Previous African records only from Cameroon, Tanzania, Uganda and D.R. Congo. A comparatively scarce pantropical species.

Bryoerythrophyllum campylocarpum (Müll. Hal.) H.A.Crum Eleven collections, spread across the plateau, on soil and alluvium, occasionally on rock, in forest and open areas, 1000-2260 m, Wigginton 1749b, 1750a; Hodgetts 2021e, 2024b, 2506b; Longton 8187a, 8216a, $8374 a, 8441 a, 8592 a 8598 b$. Widespread in tropical and southern Africa.

Hyophila involuta (Hook.) A.Jaeger At lower elevations, $730-1360 \mathrm{~m}$, on rock or concrete, apart from one collection on soil; Wigginton (3), Hodgetts (8), Longton (9). A widespread pantropical species.

*Leptodontium brachyphyllum Broth. \& Thér. Near Sombani Hut, $15^{\circ} 53^{\prime} \mathrm{S} 35^{\circ} 42^{\prime} \mathrm{E}$, stone in path, $2060 \mathrm{~m}, 20$ June 1991, O'Shea 7221b. Previously known in Africa only from South
Africa and Swaziland.

Leptodontium flexifolium (Dicks.) Hampe Sapitwa, $15^{\circ} 57^{\prime} \mathrm{S} 35^{\circ} 35^{\prime} \mathrm{E}$, on earth at base of grass tussocks, 2750 m, 25 June 1991, Porley 246a; dry depressions on skeletal soil on summit, 3000 m, 25 June 1991, Porley 254a; on rock, 2740 m, 25 June 1991, Magombo 4292a. This species was reported new to Malawi by Sollman (1998) based on one of these specimens (Magombo 4292a). Tropical and southern Africa.

Leptodontium longicaule var. longicaule Mitt. Malosa Pools, $15^{\circ} 54^{\prime} \mathrm{S} 35^{\circ} 42^{\prime} \mathrm{E}$, ground under ericaceous shrubs on leaf litter, $2080 \mathrm{~m}, 20$ June 1991, Kungu 3092a; Lichenya Hut, 1558'S $35^{\circ} 33^{\prime} \mathrm{E}$, ground under Cupressus, 1840 m, 26 June 1991, Longton 8452a. Eastern and southern Africa and tropical America.

*Leptodontium pungens (Mitt.) Kindb.

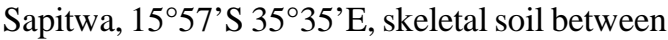
granitic outcrops on summit, 3000m, 25 June 1991, Porley 253b. Tropics of Africa and America.

Leptodontium viticulosoides var. viticulosoides (P.Beauv.) Wijk \& Margad. Madzeka Path, $15^{\circ} 58^{\prime} \mathrm{S} 35^{\circ} 40^{\prime} \mathrm{E}$, on old Brideria macrantha trunk, 1020 m, 16 June 1991, O'Shea 7025a; path to Chisongoli forest, $16^{\circ} 1^{\prime} \mathrm{S} 35^{\circ} 43^{\prime} \mathrm{E}$, Eucalyptus trunk in shrub, 1490 m, 17 June 1991, Hodgetts $2263 a$; path to Minunu Hut from Rio Gorge, $15^{\circ} 56^{\prime} \mathrm{S} 35^{\circ} 39^{\prime} \mathrm{E}$, ground amongst tussocks in Helichrysum grassland, 2000 m, 20 June 1991, Hodgetts, 2104c; Malosa Pools, 15 ${ }^{\circ} 54^{\prime} \mathrm{S}$ $35^{\circ} 41^{\prime} \mathrm{E}$, on ericaceous shrub by river, after crossing bridge to Sombani Hut, 2080 m, 20 June 1991, Kungu 3083a; Kathumba 5991a; near Sombani Hut, $15^{\circ} 53^{\prime} \mathrm{S} 35^{\circ} 42^{\prime} \mathrm{E}$, branch of dead evergreen tree in Pinus patula plantation, 2060m, 20 June 1991, Longton 8209a; Lichenya River, $15^{\circ} 58^{\prime} \mathrm{S} 35^{\circ} 33^{\prime} \mathrm{E}$, tree in riverine forest at stream edge, 1720 m, 27 June 1991, Kungu 3305a. Widespread in the tropics.

*Pseudosymblepharis bombayensis (Müll.Hal) P.Sollman Found throughout the expeditiion area from 740-2410 m, on rock, soil or trees; Porley (5), Wigginton (16), Hodgetts (19), Kungu 
(6), Kathumba (3), O’Shea (9), Longton (14). A widespread palaeotropical species.

Trichostomum brachydontium Bruch. Lichenya path to Likhubula, $15^{\circ} 57^{\prime} \mathrm{S} 35^{\circ} 33^{\prime} \mathrm{E}$, moist shaded sandstone rock at woodland edge, 2010 m, 29 June 1991, Wigginton 1721b; Brachystegia woodland 1-1.5 km from Likhubula $15^{\circ} 56^{\prime} \mathrm{S} 35^{\circ} 30^{\prime} \mathrm{E}$, on earth at base of tree and on stone in path, 900-1000 m, 29 June 1991, Hodgetts 2640b, 2641a; tributary of Likhubula River, $15^{\circ} 56^{\prime} \mathrm{S} 35^{\circ} 32^{\prime} \mathrm{E}$, ground in firebreak in open, dry woodland, 1230 m, 29 June 1991, Longton 8600a. Widespread.

*Trichostomum lorifolium Broth. \& Paris Chisongoli forest, $16^{\circ} 1^{\prime} \mathrm{S} 35^{\circ} 43^{\prime} \mathrm{E}$, rock surface in cleared forest area in grass-herb community, 1500 m, 17 June 1991, Wigginton 1110a. A few localities in west and east Africa.

*Weisiopsis plicata (Mitt.) Broth. All collections were from the southern flanks of Mulanje, from 740-1560 m, on thin patches on boulders, all but two in the shade; Porley $69 a$, 82a; Wigginton 1103c, 1104b, 1737a; Hodgetts 2264a, 2698a; O'Shea 7004a, 7007b. Eastern and southern Africa, including Madagascar.

Weissia unguiculata (Mitt.) Crundw. \& Nyholm Path from Thuchila hut to Lukhulezi, $15^{\circ} 53^{\prime} \mathrm{S} 35^{\circ} 37^{\prime} \mathrm{E}$, sandy soil in open Brachystegia woodland, 1800 m, 23 June 1991, Longton 8335a, 8336a. A few records in tropical Africa.

\section{PTEROBRYACEAE}

Calyptothecium cf. acutifolium (Brid.) Broth. Chisongoli Forest, $16^{\circ} 1^{\prime} \mathrm{S} 35^{\circ} 43^{\prime} \mathrm{E}$, trunk of mature tree in forest, $1625 \mathrm{~m}, 17$ June 1991 , Wigginton 1040a; det. A.E. Newton. Tropical and southern Africa.

Calyptothecium hoehnelii (Müll.Hal.) Lindau In forest patches across the mountain, on dead and living trees and branches, from quite light shade to deep shade, 1625-2130 m, Porley (3), Wigginton (1), Hodgetts (5), Kungu (1), Magombo (1), Kathumba (2), O’Shea (2),
Longton (1). All det. by collector or N.G. Hodgetts; about half confirmed by A.E. Newton. Tropical and southern Africa.

\section{PTYCHOMITRIACEAE}

*Ptychomitrium microblastum (Müll.Hal). Paris Likhubula River, $15^{\circ} 56^{\prime} \mathrm{S} 35^{\circ} 31^{\prime} \mathrm{E}$, rock by river, $1000 \mathrm{~m}, 30$ June 1991, Wigginton 1742a, Magombo 4409a; The Crater, Muloza River, $16^{\circ} 1^{\prime} \mathrm{S} 35^{\circ} 33^{\prime} \mathrm{E}$, flat sunny granite slab by river in Newtonia forest, 885 m. 30 June 1991, Longton $8623 a$ (all det. M.J. Wigginton). All three collections were made at comparatively low altitudes in the west and south west foothills of the mountain, areas little explored during the expedition. This distinctive species was previously known as $P$. eurybasis Dixon and is well described and illustrated in Magill and van Rooy (1998). Southern Africa, Australia and New Caledonia. [BJO]

\section{SPLACHNACEAE}

Tayloria orthodonta (P.Beauv.) Wijk \& Margad. Not particularly frequent, but found across the plateau area, on dead and living tree trunks, branches and roots, but also on the humus capping of a shaded rock; usually growing with other epiphytic bryophytes. Porley 356a; Hodgetts 2612c; Kungu 3124b; Russell 6069c; O'Shea 7227a, 7276a, 7277b, 7295a; Longton 8296a, 8530a. All specimens confirmed by T. Pócs. This plant occurs throughout sub-Saharan Africa, including the East African islands, and had been previously recorded in Malawi from both Mulanje Mt. and Nyika Plateau.

*Tayloria solitaria (Hedw.) T.J.Kop \& W.Web. Chisongoli forest, $16^{\circ} 1$ 'S $35^{\circ} 44^{\prime} \mathrm{E}$, branch of tree in forest, with Zygodon, Lophocolea, Schiffneriolejeunea and other bryophytes, 1680 m, 17 June 1991, Wigginton 1098f, conf. B.J. O'Shea. Widely distributed in the mountainous areas of tropical Africa, and extending into Madagascar, but quite scarce throughout the range.

\section{SYMPHYODONTACEAE}


*Symphyodon pygmaeus (Broth.) S.He \& Snider Chapaluka path to Chambe Basin, $15^{\circ} 55^{\prime} \mathrm{S} 35^{\circ} 32^{\prime} \mathrm{E}$, epiphytic on liane by side of path, 1420 m, 7 August 1993, C.R. Stevenson MW139, det. M.J. Wigginton, conf. B.J. O’Shea. The first collection of this taxon for mainland Africa was from about $170 \mathrm{~km}$ away from Mulanje Mt. in neighbouring Mozambique, and was described in Ochyra \& Pócs (1987[“1985”]), who include an excellent description and illustration. It has since been found in Ethiopia, and occurs also on Madagascar and Reunion. Further collections of this small, pretty moss are clearly possible in the Afromontane area. The taxon was also covered in the recent revision of this genus by He \& Snider (2000), who include Nepal, India, Thailand, China and Hawaii in its distribution. [BJO]

\section{THUIDIACEAE}

All collections determined by A. Touw. A major treatment of Thuidiaceae by Dr Touw will be published shortly, so information here is limited to collection data and comments on distribution in Malawi.

Thuidium chenagonii Müll.Hal. ex Renauld \& Cardot Found in moist forest areas on the $S$ and SE flanks of the mountain, between 730-1290 $\mathrm{m}$, but mostly below $1000 \mathrm{~m}$. It occurred on boulders and dead and living trees, often by streams, usually with other pleurocarps in a bryophyte mat. Porley 79a; Wigginton 1132c, 1426c; Magombo 4086a; Kathumba 5166a, 5913a; Russell 6033c; O'Shea 7076b, 7089a, 7543a, 7554a, 7588a; Longton 8017c. Not previously reported for Mulanje Mt., but known from three other mountains in Malawi.

*Thuidium matarumense Besch. Minunu to Chinzama track, $15^{\circ} 54^{\prime} \mathrm{S} 35^{\circ} 38^{\prime} \mathrm{E}$, under ericaceous shrub, $2020 \mathrm{~m}$, 20 June 1991, O'Shea $7183 b$; Thuchila Plateau, $15^{\circ} 54^{\prime} \mathrm{S} 35^{\circ} 37^{\prime} \mathrm{E}$, dry boulder top in forest, $1880 \mathrm{~m}, 22$ June 1991, Porley 192a; W slopes of False West Peak, $15^{\circ} 56^{\prime} \mathrm{S} 35^{\circ} 34^{\prime} \mathrm{E}$, on ground among boulders in gully, 2375 m, 28 June 1991, Longton 8576a. This montane species is an interesting new find in Malawi. It is the only Malawi species from subg. Thuidium; all the rest belong to subg.
Microthuidium (= Cyrtohypnum). [BJO]

Thuidium ramusculosum Mitt. By far the most frequently collected Thuidium, growing from $700-2320 \mathrm{~m}$, mainly on the plateau at around $2000 \mathrm{~m}$, on rocks, rotting logs, trees and soil, mainly in forested areas, in mixed bryophyte mats. 54 collections: Porley (4); Wigginton (9); Hodgetts (4); Kungu (5); Magombo (1); Kathumba (6); O'Shea (20); Longton (3); Rammeloo (2). Wigginton $1489 a$ is unusual in being the only foliicolous Thuidium amongst the collections. Known previously in Malawi from Chinteche, Limbe, Zomba, Mulanje and Ntchisi. [BJO]

Thuidium varians Welw. \& Duby Found from 740-1625 m, but mainly below $1000 \mathrm{~m}$, on the $\mathrm{S}$ and SE slopes of the mountain, but also once on the drier NW slopes, in shade in forests, on rocks, soil, tree trunks and roots and dead trees. Wigginton 1167a, 1175c, 1734a; Hodgetts 2277a, 2297a; Magombo 4019a; Kathumba $5196 a$; Longton 8064b. Previously known in Malawi only from Mt. Ntchisi.

Thuidium versicolor Müll.Hal. Thuchila Plateau, $15^{\circ} 53^{\prime} \mathrm{S} 35^{\circ} 36^{\prime} \mathrm{E}$, rocks in forest, 1760 m, 23 June 1991, Wigginton 1428a; Path down to Likhubula Forestry Office, $15^{\circ} 56^{\prime} \mathrm{S} 35^{\circ} 30^{\prime} \mathrm{E}$, rock by road, 850 m, 30 June 1991, Magombo $4394 b$. Previously collected in Malawi only once, by A.C. Crundwell on Zomba Plateau.

\section{TRACHYPODACEAE}

Trachypodopsis serrulata (P.Beauv.) M.Fleisch. In forest across the plateau, but not collected in the forests at lower elevations, 1720-2320 m, shady conditions, sometimes by streams, usually on rocks or corticolous (on tree trunks alive or dead, twigs, lianes, tree ferns, shrubs) but also recorded from soil in the shade of a rock; Porley (4), Wigginton (5), Hodgetts (6), Kungu (1), Magombo (3), Kathumba (4), O'Shea (6), Longton (6); all det. NGH. Many specimens were intermediate between $T$. serrulata and $T$. laxoalaris, casting some doubt on the taxonomic validity of $T$. laxoalaris. Found in montane forests across tropical Africa and Asia. [NGH] 


\section{ACKNOWLEDGEMENTS}

We are most grateful to H. Bischler, R. Grolle, J. Hasegawa, R.E. Magill, B.M. Murray, S.M. Perold, T. Pócs, P. Rao, P. Sollman, I.G. Stone, A. Touw, J. Ván̆a and K. Yamada for identifying or commenting on selected collections.

\section{REFERENCES}

Arnell, S. 1956. Hepaticae collected by O. Hedberg et al. on the East African mountains. Arkiv för Botanik ser. 2. 3: 517-562.

Bruggeman-Nannenga, M.A. 1993. Taxonomic results of the BRYOTROP expedition to Zaire and Rwanda 15. Fissidentaceae. Tropical Bryology 8: 141-148.

Bruggeman-Nannenga, M.A. 1997. Notes on Fissidens VI. New Synonyms, new combinations and validation of some names. Journal of the Hattori Botanical Laboratory 81: 155-173.

Bruggeman-Nannenga, M.A. \& Pursell, R.A. 1996 ['1995']. Notes on Fissidens V. Lindbergia 20: $49-55$

Chopra, N. \& Kumar, S.S. 1981. Mosses of the western Himalayas and adjacent plains. Annales Cryptogamici et Phytopathologici 5: i-xvi, 1-142.

Crosby, M.R. 1999. A checklist of Mosses . St. Louis: Missouri Botanical Garden.

Crum, H., 1973. Mosses of the Great Lakes Forest. Contribution of the University of Michigan Herbarium 10: 1-104.

Crum, H. \& Anderson, L.E. 1981. Mosses of Eastern North America. I. New York: Columbia University Press.

Eddy, A. 1988. A Handbook of Malesian Mosses, Volume 1. Sphagnales to Dicranales. London: British Museum (Natural History).

He, S. \& J. A. Snider. 2000. A taxonomic revision of Symphyodon (Musci: Symphyodontaceae). Bryologist 103: 52-81.

Kitagawa, N. 1965. A revision of the family Lophoziaceae in Japan and its adjacent regions. Journal of the Hattori Botanical Laboratory 28: 239-291.
Longton, R.E. 1993. British Bryological Society Expedition to Mulanje Mountain, Malawi. 1. Background, itinerary and procedures. Journal of Bryology 17: 633-644.

Magill, R.E. 1981. Bryophyta. Part 1. Mosses. Fascicle 1. Sphagnaceae-Grimmiaceae, In: O.A. Leistner (ed.), Flora of Southern Africa Pretoria: Botanical Research Institute, Department of Agriculture and Fisheries.

Magill, R.E. \& van Rooy, J. 1998. Bryophyta. Part 1. Musci. Fascicle 3. Erpodiaceae-Hookeriaceae, In: O.A. Leistner (ed.), Flora of Southern Africa . Pretoria: National Botanical Institute.

Meenks, J. \& Pócs, T. 1985. East African Bryophytes IX. Aneuraceae. Abstracta Botanica 9: 79-98.

Müller, F. 1996. Beitrag zur Moosflora der Insel Bioko (=Fernando Po), Äquatorial-Guinea. Tropical Bryology 12: 75-96.

Ochyra, R. \& Pócs, T. 1987['1985']. East African Bryophytes, XI. Dr. L. Péntek's collection from Mozambique. Abstracta Botanica9, Suppl. 2: 6386.

O'Shea, B.J. 1993. British Bryological Society Expedition to Mulanje Mountain, Malawi. 2. Checklist of Malawi bryophytes. Journal of Bryology 17: 645-670.

O'Shea, B.J. 1999. Checklist of the mosses of subSaharan Africa (version 3, 11/99). Tropical Bryology Research Reports 1: 1-133.

Perold, S.M. 1995. A survey of the Ricciaceae of tropical Africa. Fragmenta floristica et geobotanica 40: 53-91.

Pócs, T. 1990. The exploration of the East African Bryoflora. Tropical Bryology 2: 177-191.

Sollman, P. 1998. Several mosses (Pottiales) new or rarely collected in Africa. Tropical Bryology 14: 21-24.

Smith, A.J.E. 1978. The moss flora of Britain and Ireland. Cambridge: Cambridge University Press.

Tewari, S. D. \& Airi, S.K. 1988. Chandonanthus birmensis Steph. and C. hirtellus (F.Weber) Mitt., additions to the liverwort flora of the northwestern Himalayas. Lindbergia 14: 123-125.

Vanden Berghen, C. 1965. Hépatiques récoltées par Dr J.-J. Symoens dans la région péri-tanganyikaise. Bulletin de la Société Royale de Botanique de Belgique 98: 129-174

Wigginton, M.J. \& Grolle, R. 1996. Catalogue of the Hepaticae and Anthocerotae of sub-Saharan Africa. Bryophytorum Bibliotheca 50: 1-267. 